\title{
Metropole, Colony, and Imperial Citizenship in the Russian Empire
}

\author{
ALEXANDER MORRISON
}

\begin{abstract}
We are not Englishmen, who in India strive by no means to mingle with the native races and who for this reason, sooner or later, may pay with the loss of that country, where they will have no ties of relationship; our strength, by contrast, up until now has consisted in that we assimilated the defeated peoples, blending with them peacefully.
\end{abstract}

-Mikhail Veniukov'

Russia's supposedly ambivalent identity between Europe and Asia long exercised a peculiar fascination for historians seeking to understand the nature of Russian imperialism. In the 19th century, an era when it is often assumed that biological racism and the creation of difference were becoming a universal justification for colonial rule, the Russian Empire was seen, and has continued to be seen, as an intriguing exception. As the opening quotation from the famous military geographer Mikhail Veniukov suggests, there has never been any shortage of those prepared to claim that Russian imperialism was distinctively tolerant and assimilationist when contrasted with the imperialism of the other European powers. Ideas of pan-Asian kinship and a seeming lack of political privileges for Russians suggested that access to power was determined largely by social status rather than ethnicity or religion, with the Russians themselves becoming the victims of their own imperial enterprise. ${ }^{2}$ The existence of an "Asianist" imagined geography of the empire appeared to set Russian imperial culture apart from that of

The debt which this paper owes to the work of other scholars will be obvious-it is not a piece of original research, merely an attempt at synthesis. I would like to thank Mike Hughes, Catriona Kelly, Norihiro Naganawa, Tomohiko Uyama, Paul Werth, and the anonymous reviewers of Kritika for their valuable advice and suggestions.

M. I. Veniukov, "Postupatel'noe dvizhenie Rossii v Srednei Azii," Sbornikgosudarstvennykh znanii, 3, ed. V. P. Bezobrazov (St. Petersburg: V. Bezobrazov, 1877), 61.

Geoffrey Hosking, Russia: People and Empire, 1558_1917(London: HarperCollins, 1997).

Kritika: Explorations in Russian and Eurasian History 13, 2 (Spring 2012): 327-64. 
Britain or France. ${ }^{3}$ The most common alternative to this view of Russian imperialism was nationalist historiography which described the empire and its Soviet successor as a "prison of peoples," or at the very least understood Russia's imperial history as a series of separate national historiographies. ${ }^{4}$ Both sides of this debate were heavily influenced by emigre writings, from the self-indulgent fantasies of the "Eurasianists" to the polemics produced by disappointed Ukrainian, Georgian, or Tatar exiles, who claimed that a brief moment of national independence had been crushed by a new and still darker form of Russian imperialism. ${ }^{5}$ While the latter school at least acknowledged the empire's diversity and tried to give a (very partial) idea of what had destroyed the tsarist regime, neither made any real attempt to understand how it had functioned and held together for so long, beyond invoking either mystic geographical determinism or the use of force. Above all, perhaps, both approaches privileged the study of identity through the written products of high culture at the expense of making serious attempts to understand how such a vast polity was governed.

The "imperial turn" in both Russian and Western scholarship since the early 1990s (prompted in large part by the opening up of provincial archives in the former USSR, which finally allowed Western historians to do serious empirical research on Russian rule over non-Russians) has seen an extraordinary blossoming of works that increasingly try to understand the empire on its own terms. ${ }^{\circ}$ Dominic Lieven's and Kimitaka Matsuzato's calls for a greater focus on the reasons for imperial cohesion, rather than the artificially divided "national" historiographies that emerged between the 1970s and the 1990s, has been widely answered; and recent scholarship has placed a greater and welcome emphasis on exploring the empire's territorial divisions and administration and on the plurality of regional approaches to governance.?

"Mark Bassin, "Geographies of Imperial Identity," in Cambridge History of Russia, ed. Dominic Lieven (Cambridge: Cambridge University Press, 2006), 2:60—63.

"The series of "national" histories of the Tatars, Kazakhs, Uzbeks, etc., produced by the Hoover Institution were perhaps the preeminent example of this.

s On "Eurasianism," see Nicholas V. Riasanovsky, "The Emergence of Eurasianism," California Slavic Studies 4 (Berkeley: University of California Press, 1967), 39-72; and Marlene Laruelle, L'ideologie eurasiste russe, ou Commentpenser l'Empire (Paris: L'Harmattan, 1999). For many years, the most influential "nationalist" interpretation of Russian imperialism was Richard Pipes, The Formation of the Soviet Union (Cambridge, MA: Harvard University Press, 1954, repr. 1964 and 1997)

From the Editors, "The Imperial Turn," Kritika 7, 4 (2006): 705-12.

Dominic Lieven, Empire: The Russian Empire and Its Rivals (London: John Murray, 2000); Kimitaka Matsuzato, "Introduction," in Imperiology: From Empirical Knowledge to Discussing the Russian Empire, ed. Matsuzato (Sapporo: Slavic Research Center, 2007), 12-13. 
Perhaps the most prominent and ambitious example of this new trend is a collective volume edited by Jane Burbank, Mark von Hagen, and Anatolyi Remnev, which offers a rich variety of perspectives on the peoples, places, and hierarchies of the Russian Empire. ${ }^{8}$ Not one of the contributions to this book, however, deals with the Russian Empire's most obviously colonial region, Central Asia. This is a serious omission: Turkestan and the steppe cannot be viewed as uncharacteristic administrative anomalies which somehow do not fit an alternative, all-Russian pattern. Central Asia is too important both to late imperial thinking about Russia as a colonial power, and to the experience of the empire's largest religious minority, its Muslims (most of whom lived there), not to be at the center of any analysis of Russian imperialism. ' This article aims to engage with and revise some of the conclusions of this debate by approaching it from a Central Asian perspective. Seen from the empire's remotest and most "un-Russian" region, many of the controversies regarding imperial policy at the center seem at best irrelevant and at worst misleading. Regional studies of Islam in the Russian Empire have a tendency to take the Volga - Ural region as the norm for Muslim interaction with the tsarist state, from which other regions deviate, or else to assume that the pattern established there was simply reproduced elsewhere. ${ }^{10}$ Elena Campbell's article on the "Muslim Question" in late imperial Russia is typical of this tendency: though it is a reasonable description of late imperial debates surrounding the Tatars of Kazan province, it takes these as characteristic of the empire as a whole." In concentrating on opinions within the Ministry of the Interior and among Orthodox missionaries, it almost entirely ignores the views of the military. Yet 60 percent of the empire's Muslims - in the steppe, the North Caucasus, and Central Asia-lived in provinces under military rule, where they did not fall under the jurisdiction of the spiritual assemblies in Orenburg, Transcaucasia, and Crimea, the structures of the "confessional state" that have formed the focus of most recent research on the tsarist state's relationship

\footnotetext{
: Jane Burbank, Mark von Hagen, and Anatolyi Remnev, eds., Russian Empire: Space, People, Power, 1700_1930 (Bloomington: Indiana University Press, 2007).

- The volume that best fills this sizable gap is Tomohiko Uyama, ed., Empire, Islam, and Politics in CentralEurasia (Sapporo: Slavic Research Center, 2007).

10 Robert D. Crews, For Prophet and Tsar: Islam and Empire in Russia and Central Asia (Cambridge, MA: Harvard University Press, 2006); Crews, "An Empire for the Faithful, a Colony for the Dispossessed," in Le Turkestan russe: Une colonie comme les autres? ed. S. Gorshenina and S. Abashin (Cahiers d'Asie centrale, no. 17/18) (Tashkent and Paris: IFEAC, 2009): $82 \longrightarrow 83$.

"Elena Campbell, "The Muslim Question in Late Imperial Russia," in Russian Empire, $320^{\wedge} 7$.
} 
with Islam. ${ }^{12}$ If there was such a thing as Russian citizenship, then they were clearly excluded from it.

As Yanni Kotsonis has observed, "If citizenship is understood as the endowment of rights on an individual basis, balanced by duties for which one is individually responsible, then the imperial order of estates and autocratic rule was inhospitable terrain for the development of the modern practices of citizenship." ${ }_{13} \mathrm{He}$ and others have argued convincingly that the concept is, nevertheless, useful for historians of the Russian Empire, if only because the vocabulary of citizenship was used so extensively by state and private actors in the 19th century. ${ }^{14}$ That this liberal vocabulary was not always a good way of describing the actual relationship between the state and its inhabitants is certainly true. It is no less true that the recognition of cultural diversity, combined with legal and administrative pluralism which some scholars have recently identified as characteristic of Russian "citizenship," in practice tell us more about the necessities of governance than about citizenship per se. ${ }^{15}$ As an aspiration, however, citizenship remained important for both bureaucratic reformers and members of the intelligentsia, and its impact can clearly be seen both in the period of the Great Reforms and in the fierce political debates of the early 1900s.

This article does not seek to establish a conceptual definition of what citizenship meant in tsarist Russia. Although until its demise in 1917 the tsarist regime did not extend even to the majority of its European subjects those rights that Western historians normally associate with "citizenship," I am not seeking to measure citizenship in the Russian Empire either against an abstract ideal or against the West. Instead this article is concerned with the relative inequalities that existed between different categories of subject and territory and the parallels between inequalities in Russia and in other European empires. For this purpose, what matters are not the absolute rights that Russian citizens enjoyed or the duties they had to bear, but the extent to which these differed from those who were placed outside this category. I argue that from the 1860 s onward, and in some respects before, Russia saw the creation of legal and administrative

12 V. O. Bobrovnikov, "Islam in the Russian Empire," Cambridge History of Russia, 2:210_-17. The proportion is calculated according to the 1897 census data given in Andreas Kappeler, The Russian Empire: A Multi-Ethnic History (London: Longmans, 2001), 397—99.

${ }_{13}$ Yanni Kotsonis, " 'Face-to-Face': The State, the Individual, and the Citizen in Russian Taxation, 1863-1917," Slavic Review 63, 2 (2004): 221.

${ }^{14}$ See the essays in Kritika 7, 3 (2006), "Subjecthood and Citizenship, Part II: From Alexander II to Brezhnev"; and Joseph C. Bradley, "Subjects into Citizens: Societies, Civil Society, and Autocracy in Tsarist Russia," American Historical Review 107, 4 (2002): $1094-1123$.

${ }_{15}$ This criticism is made strongly by Timothy Snyder, "The Elusive Civic Subject in Russian History," Kritika 7, 3 (2006): 609-17. 
differences that offer some parallels to the division between metropole and colony seen in the British and French empires.

Despite the exaggerated claims that are sometimes made for the importance of the "Asian" imagining of empire in Russia, Asianism had little impact on the way the empire was ruled or on the imagination of most of its officials. ${ }^{16}$ Rhetorical claims to kinship with subject peoples and territories of the kind made by Veniukov could also be found in the French and British empires (one of the most prominent being the notion of "Aryan brotherhood," which also had considerable currency in Russia), and they tell us little about the reality of colonial rule. ${ }^{17}$ Kinship could sometimes be just as useful as the establishment of "difference" between ruling and subject peoples in justifying the maintenance of empire. ${ }^{18}$ This point is often overlooked by scholars in the quest to identify and excoriate the biological racism, Orientalism, social Darwinism, and other -isms that were employed by 19th-century thinkers, administrators, soldiers, and churchmen to excuse, defend, or strengthen imperialism by demonstrating the manifest inferiority of subject peoples and their unfitness to govern themselves." For the British and French in particular, the need to justify ruling over Asian and African peoples

16 For an early critique of the notion that Russia has a uniquely inclusive or tolerant relationship with Asia, see Nicholas V. Riasanovsky, "Asia through Russian Eyes," in Russia and Asia, ed. Wayne S. Vucinich (Stanford, CA: Hoover Institution Press, 1972), 3-29. See further Jeff Sahadeo, Russian Colonial Society in Tashkent (Bloomington: Indiana University Press, 2007), 5; Adeeb Khalid, "Culture and Power in Colonial Turkestan," in Le Turkestan russe, 418.

F. Max Miiller, Lectures on the Science of Language Delivered at the RoyalInstitution of Great Britain in April, May, andJune 1861 (London: Longmans, Green, and Co., 1861), 1:199; Joan Leopold, "The Aryan Theory of Race," Indian Economic and Social History Review 7 (1970): 271-97; T. R. Trautmann, Aryans and British India (Berkeley: University of California Press, 1997); Tony Ballantyne, Orientalism and Race: Aryanism in the British Empire (Basingstoke, UK: Palgrave Macmillan, 2002); Marlene Laruelle, Mythe aryen et reve imperial dans la Russie duXIXesiecle (Paris: Editions CNRS, 2005).

${ }_{18}$ Joan Leopold, "British Applications of the Aryan Theory of Race to India, 1850_1870," English Historical Review 89, 352 (1974): 592. It is instructive to compare Veniukov's writings on Central Asia with those of the legal anthropologist Henry Maine on India: Veniukov, "Postupatel'noe dvizhenie Rossii v Srednei Azii," 60; Henry Sumner Maine, Lectures on the Early History of Institutions (London: John Murray, 1880), 18-19. Both use the idea of "Aryan kinship" as a justification for conquest and European domination in Asia.

19 Ann Laura Stoler, "Sexual Affronts and Racial Frontiers: European Identities and the Cultural Politics of Exclusion in South-East Asia," in Tensions of Empire: Colonial Cultures in a Bourgeois World, ed. Stoler and Frederick Cooper (Berkeley: University of California Press, 1997), $198-237$. 
without their consent became acute in the 19th century because it stood in increasingly stark contrast to the way they conducted government at home. So long as empires were ruled by dynasties and despots, with little or no differentiation of political rights between metropole and colony, there was little need for such strategies. After the American and French revolutions, the idea that government should be by consent of the populace helped accelerate the move toward the nation-state, where political, linguistic, and cultural boundaries were supposed to coincide. But the 19th century was as much, if not more, a century of empires_-of large, multi-ethnic polities, often with varying hierarchies of political rights. ${ }^{20}$ This presented a dilemma to political thinkers across the spectrum, but particularly to those of a radical or liberal persuasion who believed in the universal rights and brotherhood of man. Some became committed anti-imperialists, but many more found ingenious ways of drawing boundaries around the democratic political community, at the same time preserving democracy at "home," in the metropole, but denying it to those in the colonies over which an increasingly democratic government exercised control. In 1837, Alexis de Tocqueville advocated distinct legal and political systems for settlers and Muslims in Algeria. Initially he had envisaged this distinction as a temporary measure "until two peoples different in civilization should fuse into a single whole." ${ }^{21}$ Already by 1841 , however, the 19th century's most famous writer on democracy and society had concluded that, while European settlers could and should be granted the rights of French citizens, the Muslims of North Africa would never form a part of the French political nation:

The fusion of these two populations [Muslim and Christian] is a chimera that people dream of only when they have not been to these places. There can, therefore, and there must, be two very distinct legislative systems in Africa, because there are two very separate societies there. When it comes to the Europeans, nothing absolutely prevents us from treating them as though they were alone, since the rules that we make for them never have to apply to anyone but them..$^{2}$

${ }^{20}$ The standard modern narrative of the demise of empire and the rise of the nation-state is subjected to a sustained and effective critique in Jane Burbank and Frederick Cooper, Empires in World History: Power and the Politics ofDifference (Princeton, NJ: Princeton University Press, 2010). See also "Interview with Jane Burbank and Frederick Cooper," Ab Imperio, no. 2 (2010): $22-45$.

${ }_{21}$ Alexis de Tocqueville, "Lettre sur l'Algerie" (1837), in Tocqueville sur l'Algerie, ed. S. L. Boulbina (Paris: Flammarion, 2003), 56.

22 Alexis de Tocqueville, "Essay on Algeria" (1841), in Writings on Empire and Slavery, ed. and trans. Jennifer Pitts (Baltimore: Johns Hopkins University Press, 2001), 111; de Tocqueville, "Travail sur l'Algerie" (1841), in Tocqueville sur l'Algerie, 168. 
Despite continuing rhetoric about "assimilation," this would remain true of French imperialism until its dying years after World War II, with only a tiny elite ever becoming evolue and gaining French citizenship. ${ }^{23}$

What was true of French imperialism was still truer of the British Empire, within whose complex web of dominions, protectorates, and crown colonies there was one fairly consistent pattern. In theory, all the inhabitants of the empire were subjects of the Crown, and not citizens at all, but in practice, the populations of the metropole, the self-governing white-majority dominions of Canada, Australia, New Zealand, and later the white-minority regimes of South Africa and Rhodesia, enjoyed political rights which the so-called "tropical" colonies did not have. Although ostensibly applying to particular territories, the boundaries of imperial citizenship coincided closely with those of race. As the politician and historian Thomas Babington Macaulay put it in a speech to Parliament on the renewal of the East India Company's charter in 1833:

We have to solve one of the hardest problems in politics. We are trying to make brick without straw, to bring a clean thing out of an unclean, to give a good government to a people to whom we cannot give a free government. In this country, in any neighbouring country, it is easy to frame securities against oppression. In Europe, you have the materials of good government everywhere ready to your hands. The people are everywhere perfectly competent to hold some share, not in every country an equal share, but some share of political power. If the question were, what is the best mode of securing good government in Europe? the merest smatterer in politics would answer, representative institutions. In India you cannot have representative institutions. Of all the innumerable speculators who have offered their suggestions on Indian politics, not a single one, as far as I know, however democratical his opinions may be, has ever maintained the possibility of giving, at the present time, such institutions to India. ${ }^{24}$

Macaulay's caveat, "at the present time," was important: as a Utilitarian radical and evangelical Christian, he did not believe that Indians were essentially incapable of coping with representative government, merely that it would take many years of just laws, enlightened education, and true religion to override centuries of backwardness and produce that "class of persons

${ }_{23}$ Martin Deming Lewis, "One Hundred Million Frenchmen: The 'Assimilation Theory' in French Colonial Policy," Comparative Studies in Society and History 4, 2 (1962): 129-53; Frederick Cooper, Africa since 1940: The Past of the Present (Cambridge: Cambridge University Press, 2002), 38-65.

2 4 Thomas Babington Macaulay, "Government of India (10th July 1833)," in The Speeches of Lord Macaulay, Corrected by Himself(London: Longmans, Green, and Co., 1860), 135. 
Indian in blood and colour, but English in tastes, in opinions, in morals and intellect," which he saw as an ultimate goal of British rule. ${ }^{25}$ Though milder than the biological racism which became more common toward the end of the 19th century, this developmental justification for differential political rights, if indefinitely prolonged, could be just as effective. Seventy years later, the Liberal parliamentarian and historian James Bryce revealed how the two ideas were combined when he spoke of the distinction within the empire between the white dominions and those areas "where we deem that this native population is not qualified by its racial characteristics and by its state of education and enlightenment to work self-governing institutions." ${ }_{26}$ Ironically enough, it was only two years later that the British were compelled to give limited recognition to growing Indian political ambitions by introducing provincial elected assemblies under the Morley-Minto Reforms.

Indians (but not Britons) born in British India were legally "non-European Natural-born British Subjects," while those born in the princely states were merely "British Protected Persons." In neither case did they have anything approaching a common citizenship with those born in the metropole. This attracted increasing criticism from a new generation of Indian politicians, who attacked the system of government in India by pointing to the Crown's own commitment in the proclamation of sovereignty over the subcontinent in 1858, which stated: "We hold ourselves bound to the Natives of our Indian territories by the same obligations of duty which bind us to all our other subjects." (The system of government that actually existed in India is better described as military despotism tempered by law.)

The introduction of English education, with its great, noble, elevating, and civilising literature and advanced science, will for ever remain a monument of good work done in India and a claim to gratitude upon the Indian people. This education has taught the highest political ideal of British citizenship and raised in the hearts of the educated Indians the hope and aspiration to be able to raise their countrymen to the same ideal citizenship. This hope and aspiration as their greatest good are at the bottom of all their present sincere and earnest loyalty, in spite of the disappointments, discouragements, and despotism of a century and half. ${ }^{27}$

\footnotetext{
${ }_{25}$ Thomas Babington Macaulay, "Minute on Indian Education" (1835), in The Great Indian Education Debate: Documents Relating to the Orientalist - Anglicist Controversy, ed. Lynn Zastoupil and Martin Moir (Richmond: Curzon, 1999), 171.

${ }_{26}$ James Bryce, "Some Difficulties in Colonial Government Encountered by Great Britain and How They Have Been Met," Annals of the American Academy of Political and Social Science 30 (1907): 19.

${ }_{7}$ Dadabhai Naoroji, Poverty and Un-British Rule in India (London: Swan Sonnenschein and Co., 1901), vi.
} 
Civis Britannicus sum - the idea that a British subject had certain rights that would be upheld and enforced by his government around the world, invoked by Palmerston with reference to the Don Pacifico affair in 1860-was a powerful but two-edged ideology of empire. ${ }^{28}$ Dadabhai Naoroji was a living example of the paradoxes of British imperial citizenship: an Indian elected to Parliament as the Liberal MP for Finsbury in 1892 (by five votes), but who could not aspire to a similar position of democratically bestowed authority in his own country. In some ways, this could be represented as a triumph over the racial hierarchies of the British Empire, exemplified in Lord Salisbury's comment, made during Naoroji's earlier attempt at election in 1886, that the electors of Holborn were not yet ready to choose a "black man." As Antoinette Burton has shown, the public furor that followed Salisbury's remark actually tended to reify certain racial categories. The crucial points were that Naoroji was not black, that Asians were superior to Africans, and that while the latter were not the equals of Europeans, Naoroji was a gentleman and deserved to be treated as such. The incident may subsequently have helped him secure election in 1892. ${ }^{29}$ During his three-year tenure as an MP, Naoroji attempted to turn Westminster into a truly imperial parliament that could represent India's interests as well as those of the British public, but he was stymiednot by racism as such but by the general indifference MPs showed toward imperial affairs.

A few years later, Mohandas Karamchand Gandhi would discover that in England he could to some extent be accepted as an equal, enroll at the Inns of Court and qualify as a barrister, and even narrowly escape being married off to an English girl, yet still find the boundaries of color rigid on the train to Pretoria, where any appeal to a common imperial citizenship was futile. ${ }^{30}$ Even so, when the Second Boer War broke out in 1899, he wrote: "If I demanded rights as a British citizen, it was also my duty, as such, to participate in the defence of the British Empire," and he famously served as a stretcher-bearer at the battle of Spion Kop, together with many other Indians whom he had persuaded to join him..$^{31}$ The idea that the rights and liberties of Britons should be extended to other subjects of the empire was almost the first rhetorical weapon to be employed by the Indian nationalist movement, not

\& Daniel Gorman, Imperial Citizenship: Empire and the Question of Belonging (Manchester: Manchester University Press, 2008), 13-14.

${ }_{29}$ Antoinette Burton, "Tongues Untied: Lord Salisbury's 'Black Man' and the Boundaries of Imperial Democracy," Comparative Studies in Society and History 42, 3 (2000): 632—61.

30 M. K. Gandhi, An Autobiography: The Story of My Experiments with Truth (Ahmedabad: Navajivan Trust, 1927), 58-62, 103-4.

${ }^{31}$ Ibid., 198. 
least because the superiority of British political institutions had so often been advanced as a justification for imperial rule. Gandhi and other nationalist leaders would campaign against the color bar and the use of indentured labor in South Africa under the banner of an organization called "The Imperial Citizenship Association." ${ }^{32}$ On its own, of course, this was never enough; and by the 1920s, the Indian nationalist movement was appealing to much more radical ideas, many of which were not of British origin. Still, it would never lose its parliamentary, democratic form. The flip side of the failure of the early Indian nationalists to persuade the British to accept them as equal citizens was the failure of projects for an imperial citizenship that would have united the white settlers in the Dominions with the Mother Country, advanced by the likes of John Buchan or Lionel Curtis. ${ }^{33}$

On the face of it, the tsarist regime was never presented with a similar political dilemma. Burbank and von Hagen suggest that Russia was not drawn fully into the "imperial tension" between empire and ideals of equal citizenship, and that this constitutes an important distinction between "bourgeois" and "absolutist" empires..$^{34}$ If this tension was absent, it was in part because the Russian nation remained so ill-defined. Andrei Zorin and Nathaniel Knight have argued that Count Sergei Uvarov's notion of "Official Nationality" or narodnost', which was one of the three pillars of the new state ideology together with Autocracy and Orthodoxy, explicitly rejected the Western liberal idea of nationality and was instead strongly dynastic. ${ }^{35}$ Alexei Miller qualifies this, pointing out that Uvarov also offered support to historians who wrote about Russian narodnost' in liberal terms, but even though the ideology he promoted borrowed aspects of European thought in order to strengthen and bureaucratize the tsarist state, it was both pragmatic and

\footnotetext{
32 M. K. Gandhi, "Retaliation Is No Solution," Young India, G—T September 1919, in The CollectedWorks of Mahatma Gandhi, ed. K. Swaminathan (Delhi: Ministry of Information and Broadcasting, 1965), 16:87—89, 106—9.

${ }_{33}$ Gorman, Imperial Citizenship, $19-20$.

${ }^{34}$ Jane Burbank and Mark von Hagen, "Coming into the Territory: Uncertainty and Empire," in Russian Empire, $24-25$.

${ }_{35}$ Andrei Zorin, "Ideologiia 'pravoslaviia—samoderzhaviia—narodnosti': Opyt rekonstruktsii," Novoe literaturnoe obozrenie, no. 26 (1997): 71-104; Nathaniel Knight, "Ethnicity, Nationality, and the Masses: Narodnost'and Modernity in Imperial Russia," in Russian Modernity: Politics, Knowledge, Practices, ed. David L. Hoffmann and Yanni Kotsonis (Basingstoke, UK: Palgrave Macmillan, 2000), $54-55$.
} 
illiberal. ${ }^{36}$ Arguably, Uvarov's narodnost' helped foster a new celebration of Russian language, culture, and ethnicity, but it did not imply the creation of a political community where rights would be determined by the extent to which the tsar's subjects shared in these. In the cultural sphere the impact was admittedly profound (and in the end often productive of opposition to the state), and it also seems to have had some impact on foreign policy. Domestically, however, it did not lead to, for example, a decline in the fortunes of the Baltic German nobility, or the emancipation of Russian peasants from serfdom — at least not immediately. ${ }^{37}$ In Russia, legal and political rights and duties continued to be distributed according to social rank, religion, and occupation rather than membership of a "nation," putative or otherwise. As Gregory Freeze has shown, the concept of soslovie (the four estates of nobility, clergy, townspeople, and peasantry) which was developed in Russia from the late 18th century and persisted until 1917 is not a wholly satisfactory way of understanding even the legal regime of rights, duties, and immunities in the Russian Empire, let alone the real divisions of Russian society. Until the 1870s and 1880s, the most important juridical distinction was between those subjects who paid the poll tax and those who did not; and beyond this, there were still greater variations in the rights and obligations conferred on different groups by the state. ${ }^{38}$ Meanwhile, in the post-1860s period, soslovie acquired a whole host of meanings beyond those officially ascribed to it. Madhavan Palat has argued that the concept was even applied by the bureaucracy to factory workers, meaning that in many respects until 1917 the state continued to treat Russian society as divided, not into legal individuals with rights but into groups with ascribed, estate-like identities, duties, and privileges. ${ }^{30}$ Jane Burbank has explored the beneficial sides of this "Imperial Rights Regime": though Russian liberals might despair at the lack of equality before the law within the empire, on a practical day-to-day level, the state often provided the population with local forms of justice, marriage, and administration which accorded with familiar customs and were easily understood. ${ }^{+0}$ Russian peasants had their volost' courts, which provided easily accessible, personal

${ }^{36}$ A. I. Miller, " 'Triada' grafa S. S. Uvarova i natsionalizm," Istoricheskiezapiski, no. 11 (129) (2008): 180-98.

${ }^{37}$ Nicholas V. Riasanovsky, Nicholas I and Official Nationality in Russia, 1825-1855 (Berkeley: University of California Press, 1961), 144-46, 162, 232-33.

${ }^{38}$ Gregory L. Freeze, "The Soslovie (Estate) Paradigm in Russian Social History," American Historical Review 91, 1 (1986): 21-24.

39 Madhavan K. Palat, "Casting Workers as an Estate in Late Imperial Russia," Kritika 8, 2 (2007): 313-16, 342-48.

40 Jane Burbank, "An Imperial Rights Regime: Law and Citizenship in the Russian Empire," Kritika 7, 3 (2006): 397-431. 
justice, while Central Asian peasants had their so-called "popular judges," qazis administering Islamic law." Surely under these circumstances there was no substantive inequality between the rights (or lack of them) enjoyed by a peasant who was born a Russian subject near Smolensk and one who perforce became a Russian subject after the fall of Tashkent? That claim was certainly made by some:

\begin{abstract}
Our policy toward subject peoples is that of equal civic rights [politika grazhdanskogo ravnopraviia]. The inhabitants of cities that have only just been taken, Kuldja and Tashkent, Samarkand, etc., are immediately considered to be as much Russian citizens as those of Moscow, for instance, or perhaps even have greater privileges ... in this policy, in this Christian cosmopolitanism lies our strength. In this lies our future.
\end{abstract}

Mikhail Afrikanovich Terent'ev, a General Staff Officer and former administrator in Turkestan (who later wrote the standard history of the Russian conquest of Central Asia), also claimed that some non-Russian areas such as Finland and Poland enjoyed greater rights than Russia itself, and that the Russian peasant paid much heavier taxes than his Asiatic counterpart who, unlike him, was not liable to be conscripted. Was Terent'ev justified in making this sweeping assertion about the universal and benevolent nature of Russian imperial citizenship? Robert Crews notes that it was commonplace for Russian officials in Central Asia to invoke a higher moral purpose that focused on the supplanting of despotism and the "cries of the dispossessed," but this was a near-universal rhetorical justification for European imperialism across Asia and Africa, which was no more valid in the Russian case than in any other. ${ }^{43}$ Looking beyond the rhetoric, Terent'ev's assertion was false even in a strict legal sense, because the turemtsy (natives) of Kuldja, Samarkand, and Tashkent were not accorded equal rights with the population of European Russia.

While in Russia the division between metropole and colony, between subject and citizen, was by no means as clear as in the British and French empires, this was largely a result of the absence of a sea barrier, which helped prevent the creation of entirely separate colonial states. ${ }^{4}$ In imaginative, legal and administrative terms the barrier did exist, if only in putative form. Even in the early 19th century there was a basic distinction to be made between

\footnotetext{
On the qazis' courts in Turkestan, see Paolo Sartori, "An Overview of Tsarist Policy on Islamic Courts in Turkestan: Its Genealogy and Its Effects," in Le Turkestan russe, 477-507.

*2 M. A. Terent'ev, Rossiia i Angliia v Srednei Azii (St. Petersburg: P. P. Merkulev, 1875), 361.

3 Crews, "An Empire for the Faithful," 103.

44 Khalid, "Culture and Power," 417.
} 
Russian subjects and inorodtsy ("aliens" or "those of a different birth"),,5 a term that had taken over from inovertsy ("differently believing") in the late 18th century, although it did not acquire pejorative connotations until much later. ${ }^{46}$ Rather than representing differences in political rights, the concept of inorodtsy reflected differences in the duties of these groups toward the state: often the payment of tribute (iasak) rather than tax and exemption from military service (except in the case of the Jews). This legal category, however, could hardly be used to define Russians and non-Russians, or Orthodox and non-Orthodox, even once it had been codified by Mikhail Speranskii." Not only were some Muslim groups such as the Tatars not defined as inorodtsy, but Andrei Znamenski has identified a group of ethnically Russian Old Believers called the "rock people" in the Altai, who were declared to be iasak payers by the state in 1791 and managed to retain the status of inorodtsy for almost 90 years, only reluctantly relinquishing it in 1878 . $^{48}$ This suggests both the extent to which being an inorodets could actually bring certain benefits, and that by the later 19th century ideas of citizenship were beginning to change.

As Yanni Kotsonis has suggested, 19th-century Russia participated in a shared European framework of modernity, with Western states and societies frequently invoked as a model. The state pursued many of the same integrative strategies, but these took somewhat different forms. ${ }^{40}$ The middle years of the 19th century saw the emergence of a new Russian governmental language of graz̧ hdanstvennost', variously translated as "citizenship," "civic values," or "civic consciousness" and defined by Vladimir Dal' as the "condition

"s See John W. Slocum, "Who, and When, Were the Inorodtsy? The Evolution of the Category of Aliens in Imperial Russia," Russian Review 57, 2 (1998): 173-90, for a discussion of the changing meanings of this term as it evolved as a legal category. The most consistent meaning was that of subjects of the tsar who were nomads and hunter-gatherers, or otherwise considered to be uncivilized, but the Jews and the settled population of Turkestan represent the most important exceptions to this rule. In popular usage by the late 19th century the term often had explicitly religious and pejorative overtones.

${ }^{46}$ Kappeler, The Russian Empire, 169; Paul Werth, "Changing Conceptions of Difference, Assimilation, and Faith in the Volga-Kama Region, 1740-1870," in Russian Empire, 174.

${ }_{47}$ "Ustav ob upravlenii inorodtsev," Polnoe sobranie zakonov Rossiiskoi imperii s 1649: Sobranie pervoe s 1649po 12 dekabria 1825goda, 45 vols. (St. Petersburg: Tipografiia II-ogo Otdeleniia Sobstvennoi Ego Imperatorskogo Velichestva Kantseliarii, 1830) (hereafter PSZ), no. 29126, 22 July 1822, 394-417; Marc Raeff, Siberia and the Reforms of 1822 (Seattle: University of Washington Press, 1956), 112-28.

48 Andrei Znamenski, "The 'Ethic of Empire' on the Siberian Borderland: The Peculiar Case of the 'Rock People,' 1791-1878," in Peopling the Russian Periphery: Borderland Colonization in Eurasian History, ed. Nicholas Breyfogle, Abby Schrader, and Willard Sunderland (London: Routledge, 2007), 106-27.

49 Yanni Kotsonis, "Introduction: A Modern Paradox-Subject and Citizen in Nineteenthand Twentieth-Century Russia," in Russian Modernity, ed Hoffmann and Kotsonis, 3. 
[sostoianie] of civil society; the understanding and level of education essential for the making of civil society." ${ }_{\text {so }}$ Unlike the Western ideal of citizenship, grazhdanstvennost' did not depend upon the exercise of the vote. Nevertheless, the tenor of the concept aimed ultimately at integration, abolishing estatebased taxation, eliminating local variations in governance, and curtailing the privileges granted to local, non-Russian elites. ${ }^{51}$ In practice, however, it was often used as an exclusionary category and applied negatively to peoples considered to be at a low level of cultural development. ${ }^{52}$ The language and logic of grazhdanstvennost' are seen to particularly good effect in an 1867 ukaz sponsored by Minister of War D. A. Miliutin, which forbade the awarding of medals and other military distinctions to the leaders of Kazakh, Kalmyk, Bashkir, and other inorodtsy tribes and to the "natives" of the Caucasus. ${ }^{53}$

It has been brought to the attention of His Majesty the Emperor that the granting of military ranks and other exclusively military decorations and distinctions to Asiatics, who are still at a low level of civic consciousness [Aziiatsam, nakhodiashchimsiaeshchenanizkoistepenigrazhdanstvennosti], facilitates the maintenance among that population of warlike tendencies, when a healthy policy demands, on the contrary, that the government should with all its strength re-educate these peoples to a peaceful life and lead them to civic development [ k razvitiungrazhdanskomu].s.

Although this was outwardly an inclusive vision, which looked forward to the day when these (mainly nomadic) peoples would abandon their warlike

5. V. I. Dal', Tolkovyi slovar' z̧hivogo velikorusskogo iasyka (St. Petersburg: M. O. Vol'f, 1880), $1: 390$.

"Dov Yaroshevski, "Empire and Citizenship," Austin Lee Jersild, "From Savagery to Citizenship," and Daniel Brower, "Islam and Ethnicity: Russian Colonial Policy in Turkestan," all in Russia's Orient: Imperial Borderlands and People, 1800-1917, ed. Brower and Edward J. Lazzerini (Bloomington: Indiana University Press, 1997), 69-70, 101-11, and 115-22, respectively; Jersild, Orientalism and Empire: North Caucasus Mountain Peoples and the Georgian Frontier, 1845-1917 (Montreal: McGill-Queens University Press, 2002), 126-28; Yanni Kotsonis, " 'No Place to Go': Taxation and State Transformation in Late Imperial and Early Soviet Russia," Journal of Modern History 76, 3 (2004): 537-38.

${ }_{52}$ Tomohiko Uyama, "A Particularist Empire: The Russian Policies of Christianization and Military Conscription in Central Asia," in Empire, Islam, andPolitics, 62.

${ }_{53}$ The importance of this decree was highlighted by Dov Yaroshevski in "Empire and Citizenship," 69-70. My thanks to Professor Yaroshevski for sending me the full reference.

${ }_{54}$ "O zapreshchenii isprashivat' voinskie nagrady i v osobennosti voennye chiny Bashkiram, Kirgizam, Kalmykam i drugim inorodcheskim plemenam," Polnoe sobranie zakonov Rossiiskoi imperii: Sobranie vtoroe, 55 vols. (St. Petersburg: Tipografiia II-ogo Otdeleniia Sobstvennoi Ego Imperatorskogo Velichestva Kantseliarii, 1830-84) (hereafter PSZ 2), no. 44424a, 2 April 1867, 3; my thanks to Professor Tomohiko Uyama for pointing out to me that in practice this decree was widely ignored and that, for instance, many Kazakh leaders were decorated for their role in the conquest of Turkestan after 1867. 
tendencies and be fully incorporated into imperial civic society, it carried with it clear developmental overtones. The necessary implication was that, so long as these groups remained backward, with a low level of grazhdanstvennost', they would remain excluded from the fledgling political community that was being created in European Russia. The British and French examples show clearly enough how an ostensible commitment to admit sufficiently "developed" natives to the status of citizens could be rendered void by making the process impossibly arduous or protracted. In the Russian case, this was further complicated by the fact that in the 19th century, the empire's frontiers expanded at an unprecedented rate, incorporating new populations, which were seen as even further away from achieving grazhdanstvennost' than the groups mentioned here. Political changes at the center made that goal seem ever more remote.

One widely overlooked aspect of the Great Reforms was that they helped define what could be described as a core, metropolitan area within the Russian Empire, a growing if inconsistent distinction between the ways in which Russians and non-Russians were governed. The zemstvos, which were created by the ukaz of 1 January 1864, were not immediately introduced in the borderlands of the Russian Empire: right-bank Ukraine, Orenburg, Ufa, Astrakhan, Poland, the Baltic provinces, Archangel'sk, Siberia, the Caucasus, and Central Asia were all excluded from the initial reform, and the latter six would remain so until 1917..5 As Jorg Baberowski and Larissa Zakharova have shown, these areas were also excluded from what was perhaps the most radical of the Great Reforms, the judiciary reform. The new public, adversarial civilian courts, with their elected magistrates and peasant juries, were restricted to the central regions of European Russia; and even here, Jews and Muslims were heavily underrepresented on juries. The reformers' goal of a single legal system for the whole empire remained distant, not merely because of the retention of peasants' courts in European Russia but because of the exclusion of the "periphery" (which in fact comprised the bulk of the empire's territory) from their remit. While the reforms were not extended in the western borderlands and the Baltic provinces because of fears of local nationalism, in Turkestan and the steppe the rationale advanced for retaining local law and withholding the new civil code and jury trial was the "savagery" and "backwardness" of these regions. ${ }^{56}$ This division

Fedor A. Petrov, "Crowning the Edifice," in Russia's Great Reforms, 1855-1881, ed. Ben Eklof, John Bushnell, and Larissa Zakharova (Bloomington: Indiana University Press, 1994), 200; L. E. Lapteva, Regional'noe i mestnoe upravlenie v Rossii (vtoraia polovina XIX veka) (Moscow: Institut gosudarstvo i prava Rossiiskoi akademii nauk, 1998), 73.

${ }^{5}$ Jorg Baberowski, Autokratie und Justiz: Zum Verbdltnis von Rechtsstaatlichkeit und Ruckstdndigkeit im ausgehenden Zarenreich 1864-1914 (Frankfurt am Main: Vittorio 
both reflected and helped reinforce the division between a "core" area of "Great Russia," and an "empire" that lay beyond it, something which is not always sufficiently recognized in the literature on the subject. ${ }^{57}$ In his historical survey of viceroys, voevody, and governors, published in anticipation of the zemstvo reform, and which he felt would transform their role fundamentally, the jurist Ivan Andreevskii used revealing language when he wrote, "On this basis I have looked at these posts only with relation to Great Russia [Velikorossiia]; the examination of the corresponding posts in those provinces that now make up a part of the Russian Empire [v tekh oblastiakh, kotorye sostavliaiut teper' chasti Rossiiskoi imperii] but which have their own separate life and history, would require a dedicated work." ${ }_{58}$

The 1860s were a turning point in the history of Russian governance, not just because of the Great Reforms but because they also saw the Polish revolt (1863), victory in the Caucasus (1864), and the fall ofTashkent (1865).59 All ofthese presented the tsarist state with new challenges in ruling its borderlands, to which new strategies of control were applied. Prince Aleksandr Ivanovich Bariatinskii, the architect of Russia's victory in the Caucasus, believed that the Russians had made a grave error in adhering to their traditional policy of trying to win over and support the local nobility and tribal leaders in the region. Instead, he felt that it was precisely these groups that had been stoking "fanaticism" among the local population. ${ }^{\circ 0}$ Accordingly, from the 1850s on, both North and South Caucasian elites began to lose their privileges and their role in government. ${ }^{61}$ As Peter Holquist has shown, later Soviet

Klostermann, 1996), 365_427; Larissa G. Zakharova, "Autocracy and the Reforms of 186174 in Russia," and Alexander Afanas'ev, "Jurors and Jury Trials in Imperial Russia," in Russia's Great Reforms, 33, 222.

${ }_{57}$ The texts of the zemstvo and judicial reform legislation are reprinted in O. I. Chistiakov and T. E. Novitskaia eds., Reformy Alexandra II (Moscow: Iuridicheskaia literatura, 1998), 211 - 30, 277-336, but without the preamble indicating in which provinces they were to be applied. The editors mention the exclusion of the western provinces for fear of nationalism but not the systematic exclusion of most of the nomadic and Muslim regions of the empire (21). Peter Waldron, in Governing Tsarist Russia (Basingstoke, UK: Palgrave Macmillan, 2007), 107, writes that by the time World War I broke out, zemstvos were operating in territories containing $60 \%$ of the empire's population, but he does not devote any consideration to how the remaining $40 \%$ were governed.

5 Ivan Andreevskii, O namestnikakh, voevodakhigubernatorakh (St. Petersburg: Eduard Prats, 1864), 2.

s9 Burbank and von Hagen, "Coming into the Territory," 18.

60 Alexander Marshall, The Russian GeneralStaffand Asia (London: Routledge, 2006), 40-41.

${ }^{61}$ Jersild, Orientalism and Empire, 32-33; Firouzeh Mostashari, On the Religious Frontier: Tsarist Russia and Islam in the Caucasus (London: I. B. Tauris, 2006), 21, 27, 83 -84; M. M. Gasanov, Administrativnaiapolitika i sistema upravleniia tsarizmav Dagestane vo vtoroipolovine XIX veka (Makhachkala: Lotos, 2007), 31-33. 
ideas of "extracting" troublesome elements from the population can also be traced back to imperial policies in the Caucasus in this period. ${ }^{62}$ Elsewhere the process had begun even earlier: since the 1820s, Russian policy in the steppe had gradually undermined the authority of the Chingissid ruling elite among the Kazakhs, something that was institutionalized by the new Steppe Statute of $1868 .{ }^{63}$ This did not mean that the empire ceased to rely on the cooperation and collaboration of elements of the non-Russian population over which it ruled, but it did mean that local aristocracies would no longer be incorporated into the Russian nobility on equal terms, as had happened to the Baltic German and Georgian nobility and, to some extent, the Poles. ${ }^{64}$ While in 1897 the various Central Asian peoples made up 5.8 percent of the empire's population, only 0.15 percent of hereditary nobles came from this group: these were predominantly Kazakhs from the steppe region, most of them from the lineages of the sultans of the Inner, Middle and Bukei Hordes, whose families had acquired their privileges when they became Russian subjects in the 18th century. Nevertheless, there were almost five times as many Russian, Polish, and German nobles as Kazakhs even here, despite the fact that Kazakhs made up 77 percent of the population. In Turkestan, the contrast was still starker: Russian-speakers made up 3 percent of the population but 79 percent of its hereditary nobles. The remainder were mostly German or Polish: just 119 Kazakhs (0.01 percent of the total Kazakh population of Turkestan), 2 Kyrgyz, 1 "Sart," 3 Uzbeks, and 5 Tajiks were hereditary nobles. Another 53 speakers of all these languages had personal noble status. ${ }^{65}$ In Samarkand province, where Europeans made up less than 2 percent of the population in 1897, only 10 out of 507 hereditary nobles were drawn from the "native" population. ${ }^{6}$ Rather than reinforce existing social hierarchies through the granting of noble privileges, a new imperial

${ }_{62}$ Peter Holquist, "To Count, to Extract, and to Exterminate: Population Statistics and Population Politics in Late Imperial Russia," in A State of Nations: Empire and Nation-Making in the Age of Lenin and Stalin, ed. Ronald Suny and Terry Martin (Oxford: Oxford University Press, 2001), 116-7.

${ }_{63}$ Tomohiko Uyama, "A Strategic Alliance between Kazakh Intellectuals and Russian Administrators: Imagined Communities in Dala Walayatining Gazeti (1888-1902)," in The Construction and Deconstruction of National Histories in Slavic Eurasia, ed. Tadayuki Hayashi (Sapporo: Slavic Research Center, 2003), 247.

${ }^{64}$ Lieven, Empire, 274-75.

65 Henning Bauer, Andreas Kappeler, and Brigitte Roth, eds., Die Nationalitdten des russischen Reiches in der Volkszdhlung von 1897 (Stuttgart: Franz Steiner, 1991), vol. B, tables 30 and 46, 197, 366-67.

‘ N. A. Troinitskii, ed., Pervaia vseobshchaiaperepis ' naseleniia Rossiiskoi imperii, 1897g., 83: Samarkandskaia oblast' (St. Petersburg: Izdatel'stvo Tsentral'nogo statisticheskogo komiteta Ministerstva vnutrennikh del, 1905), 132. 
policy was formulated that attempted to separate the mass of inorodtsy from their traditional allegiances and replace these with local institutions of selfgovernment, which were supposed gradually to inculcate grazhdanstvennost'.

Bashkiria offers a particularly interesting example of this new imperial policy. This Muslim-majority borderland region was gradually demilitarized and incorporated into the "core" empire by a process oflegal and administrative reform. As Charles Steinwedel has argued, it was the transition from frontier military administration to "internal" civilian province that eventually made Bashkiria a part of "European" Russia, rather than any particularly aggressive policies of cultural assimilation. ${ }^{67}$ In religious terms, the transition dated from the founding of the Orenburg Muslim Spiritual Assembly under Catherine the Great, which many Muslims seem to have been using as a forum for the redress of grievances by the 1830s and 1840s. ${ }^{\circ 8}$ In administrative terms, reform came later, with the gradual transfer from military to civilian rule in the 1860s. The Statute on the Bashkirs (Polozhenie o Bashkirakh) of 1863 stated that "Bashkirs and other inorodtsy, forming together the current Bashkir military, [are given] equal civil [grazhdanskie] rights with other free agrarian communities and [are] to create their social administration under the general basic arrangements laid out by Us for the organization of agrarian communities." "o Two years later, this integrative measure was reinforced with the transfer of the administration of the Bashkirs of the Orenburg and Samara governor-generalship from military to civilian rule. ${ }^{70}$ In 1875 , Ufa became a zemstvo province — which, as Steinwedel suggests, reflects the judgment of the authorities that there were sufficient numbers of educated noblemen in the province to make devolved representative government work. ${ }^{71}$ In 1878, the new civilian law code was introduced; and the administrative "internalization" of what had been a frontier region was completed with the abolition of the Orenburg governor-generalship in 1881 and the extension of the zemstvo to Orenburg province in 1913. The cumulative effect of the Great Reforms as they were progressively extended to the region was to undermine the position of Bashkir landowners in the countryside, but to give them and other social groups in Ufa and Orenburg provinces the opportunity for new forms of

${ }_{67}$ Charles Steinwedel, "How Bashkiria Became Part of European Russia, 1762-1881," in Russian Empire, $94-96$.

${ }_{68}$ Robert D. Crews, "Empire and the Confessional State: Islam and Religious Politics in Nineteenth-Century Russia," American Historical Review 108, 1 (2003): 50— 83.

${ }_{69}$ "Polozhenie o Bashkirakh," PSZ 2, no. 39622, 14 May 1863, 442.

70 "O peredache upravleniia Bashkirami iz voennogo v grazhdanskoe vedomstvo," PSZ 2, no. 42282, 2 July 1865, 753-76.

${ }_{71}$ Steinwedel, "How Bashkiria Became Part of European Russia," 106. 
civic participation through the zemstvo..$^{22}$ After all these measures had been introduced, however, the Bashkirs were still not placed on an entirely equal footing even with their Tatar Muslim neighbors in Kazan province. The Statute on the Bashkirs was used by tsarist officials to facilitate the expropriation of Bashkir land and to prevent the creation of waqfendowments. It also meant that the Stolypin land reforms were never fully introduced in the region. ${ }^{3}$ Furthermore, Bashkiria represented the furthest eastward march of these new Russian civic institutions. While, as Paul Werth has argued, it is often impossible to say whether non-Russians belonged in the category of national minority or colonial subject in the more liminal areas of the empire such as Bashkiria or the Volga-Kama region, in other parts of the empire the distinction was much clearer. ${ }^{74}$

As important as understanding the implications for those minorities who were included in the new vision of Russian imperial citizenship, is understanding the reasons why other regions and peoples were excluded from them, together with the process that helped create this division, the policies that were pursued instead, and the concrete effects these policies had on those who were subject to them. The territorial divisions of the Russian Empire saw wide variations in their legal and administrative structures. Newly conquered, non-Russian regions were normally governed "at arm's length" through viceroys or governors-general, with only a simple (and often skeletal) military administration at their disposal..$^{5}$ As Leonid Gorizontov has shown, in the western borderlands, even before the Great Reform period, Russian official thinking made a clear distinction between "regular" provinces, whose territory and governance could be determined by straightforward considerations of administrative convenience and economic advantage, and "difficult," strategically vulnerable provinces, often with acute "nationality"

\footnotetext{
72 Charles Steinwedel, "Invisible Threads of Empire: State, Religion, and Ethnicity in Tsarist Bashkiria, 1773-1917" (Ph.D. diss., Columbia University, 1999), 91-95.

${ }_{73}$ I am grateful to Norihiro Naganawa for this information, which highlights the substantial variations in administrative and legal regimes which existed even within particular regions such as the Volga-Urals.

${ }^{74}$ Werth, "Changing Conceptions of Difference," 178.

A. V. Remnev and P. I. Savel'ev, "Aktual'nye problemy izucheniia regional'nykh protsessov v Imperskoi Rossii," in Imperskii stroi Rossii v regional'nom izmerenii (XIX-nachalo XX veka), ed. P. I. Savel'ev (Moscow: Moskovskii obshchestvennyi nauchnyi fond, 1997), 16-17.
} 
issues. ${ }^{76}$ Kimitaka Matsuzato has stressed the strategic imperative that dictated that sensitive border regions remain under military rule where there were either external or internal "enemies." $"$ As Tomohiko Uyama has suggested, Matsuzato's thesis requires some qualification: though legal and administrative regimes were divided on a regional basis, different laws could apply to different peoples within a particular territory. ${ }^{78}$ This was because the application of laws also depended on the perceived degree of civilization of a region's inhabitants, something that was often inextricable from their ethnicity or race. As Marina Mogil'ner has shown, the categorization of the empire's subjects according to "race" by physical anthropologists was widely diffused but inconsistently applied. If Ivan Alekseevich Sikorskii and the Kiev school had a vision of a Russian racial "core" surrounded by inferior races, the "liberal anthropology" that emerged in Moscow eschewed hierarchies and rigid divisions and instead explored kinship among different "physical types" across the empire. ${ }^{79}$ While the Russian state made relatively little use of overt biological racism as a justification for different administrative and legal regimes (with the notable exception of late imperial antisemitism), ${ }^{80}$ the developmental logic of grazhdanstvennost' meant that many peoples were excluded from its new civic institutions as too backward, untrustworthy, savage, or "fanatical," or simply because they had been conquered too recently. ${ }^{81}$

16 Leonid Gorizontov, "In Search of Internal Balance: Debate on Changes in the TerritorialAdministrative Division of the Russian Empire in the 1830s and 1840s," in Imperiology, 197-98.

77 Kimitaka Matsuzato, "General-gubernatorstva v Rossiiskoi imperii," in Novaia imperskaia istoriia postsovetskogo prostranstva, ed. Il'ia Gerasimov, Sergei Glebov, A. P. Kaplunovskii, Marina Mogil'ner, and Aleksandr Semenov (Kazan: Tsentr issledovanii natsionalizma i imperii, 2004), $447-48$.

${ }_{78}$ Uyama, "A Particularist Empire," 23-24.

79 Marina Mogilner, "Russian Physical Anthropology of the Nineteenth-Early Twentieth Centuries: Imperial Race, Colonial Other, Degenerate Types, and the Russian Racial Body," in Empire Speaks Out: Languages of Rationalization and Self-Description in the Russian Empire, ed. Ilya Gerasimov, Jan Kusber, and Alexander Semyonov (Leiden: Brill, 2009), 155—89; Mogil'ner, Homo imperii: Istoriiafizicheskoi antropologii v Rossii (Moscow: Novoe literaturnoe obozrenie, 2008), 15-19, 187-278.

${ }_{80} \quad$ See Eugene M. Avrutin, "Racial Categories and the Politics of (Jewish) Difference in Late Imperial Russia," Kritika 8, 1 (2007): 13-40, where he notes that, as in Western Europe, the impact of popular understandings of race was considerably greater than that of any state activity.

${ }^{81}$ In referring to the "backwardness" and "primitiveness" of "the lowest echelon of mostly Asiatic nationalities" Raymond Pearson unconsciously echoed the language used by tsarist officials at the time ("Privileges, Rights, and Russification," in Civil Rights in Imperial Russia, ed. Olga Crisp and Linda Edmondson [Oxford: Oxford University Press, 1989], 101). 
Until the late 19th century, and in some important cases until 1917, much of the empire's Asian territory was ruled under a system of military government called voenno-narodnoe upravlenie, which, as Vladimir Bobrovnikov has suggested, had numerous parallels with the devolved, militarized administration used in many French and British colonies. ${ }^{\mathrm{a}}$ Russian governance has attracted increasing scholarly attention, ${ }^{83}$ yet most of the literature in English does not mention the role played by the military, while most military history does not mention the army's role in government. ${ }^{s+}$ The most important characteristic of voenno-narodnoe upravlenie was a clear division between a higher bureaucracy, where executive power was reserved for military officers on permanent secondment from their regiments, and a lower or "native" administration and judiciary, parts of which were sometimes elected indirectly. In some regions, the voenno-narodnoe upravlenie co-existed with a civil judiciary that applied the general laws of the empire, but in others the law, too, was in the hands of the military. Most of the duties that in European Russia were carried out by the zemstvos and cadres associated with them fell to the lot of a small group of officers. Usually lacking specialist training, they were presented with an extremely heavy administrative burden. ${ }^{85}$ In many cases they were not equal to the task, and voenno-narodnoe upravlenie had a tendency to be both ramshackle and arbitrary. This was true in the Far East, where Remnev writes of an "administrative vacuum" below the level of governor, and in the North Caucasus. In Turkestan, a single district commandant carried out duties that would have been the responsibility of 12 or more different officials in European Russia..

${ }_{s}$ V V. O. Bobrovnikov, Musul'mane severnogo Kavkaza: Pravo, obychai, nasilie (Moscow: Vostochnaia literatura, 2002), 171-75.

${ }_{33}$ Apart from Bobrovnikov and Remnev, see also S. G. Agadzhanov, "Osnovnye cherty sistemy upravleniia natsional'nykh okrain Rossii," in Natsional'nye okrainy Rossiiskoi imperii: Stanovlenie i razvitie sistemy upravleniia, ed. Agadzhanov (Moscow: Slavianskii dialog, 1997), 394-96; M. L. Kudel'ia-Odabashian, Voenno-narodnoe upravlenie v koloniiakh Rossiiskoi imperii, XIX v.-nachalo XX veka (Moscow: Rossiiskaia ekonomicheskaia akademiia im. G. V. Plekhanova, 2003).

${ }^{84}$ This is seen to good effect in vol. 2 of the Cambridge History of Russia, where Janet Hartley, in "Provincial and Local Government" (450), specifies that she will consider only European Russia, while William C. Fuller, in "The Imperial Army" (530-53), does not mention its role in administration.

${ }_{85}$ Don K. Rowney, "The Institutional Structure of Late Tsarist Officialdom: An Introduction," in Russian Bureaucracy and the State, ed. Rowney and Eugene Huskey (Basingstoke, UK: Palgrave Macmillan, 2009), 24-25.

${ }^{86}$ A. V. Remnev, "Administrativnaia politika samoderzhaviia v Sibiri v 60-80-kh gg. XIX v.," in Sibir'v sostave Rossiiskoi imperii, ed. L. M. Dameshek and Remnev (Moscow: Novoe literaturnoe obozrenie, 2007), 125-30; Timothy Blauvelt, "Military-Civil Administration and 
Like most of the empire's administrative and cultural boundaries, those between "zemskaia Rossiia" and areas under military government shifted over time. ${ }^{87}$ The European governor-generalships of the empire were mostly liquidated in the $1850 \mathrm{~s}$ and 1860s.s ${ }^{\mathrm{s}}$ Most of the European provinces were eventually granted a modified form of zemstvo, but in areas where it was likely to prove impossible to engineer an electoral preponderance for the Great Russian nobility, they remained restricted. ${ }^{89}$ The three Baltic provinces and Grodno, Vilno, and Kovno were excluded; and continued distrust of the largely Polish nobility of the region meant considerable uncertainty about the wisdom of doing this in right-bank Ukraine and White Russia, which eventually received only so-called "margarine zemstvos" with reduced powers in $1911 . .^{\circ}$ In 1912 - 13 the zemstvo law was extended to the Asiatic fringes of European Russia, in Orenburg, Stavropol', and Astrakhan provinces, although nomadic peoples such as the Kazakhs and Kalmyks were specifically excluded from the legislation. ${ }^{91}$ The Caucasian viceroyalty was abolished in 1881, with most territories of'Transcaucasia becoming civilian gubernii on all-Russian lines (albeit without zemstvos). Meanwhile, the North Caucasus and Kars oblast remained under a form of voenno-narodnoe upravlenie that concentrated executive powers in the hands of military commandants and restricted the use of both Shari'a and the general laws of the empire in favor of local custom, or 'adat.9. When in 1905 the Caucasian viceroyalty was revived with plenipotentiary powers, the new namestnik, Prince Vorontsov-Dashkov,

Islam in the North Caucasus, 1858 -83," Kritika 11, 2 (2010): 228-32; Senator Gofmeister Graf K. K. Palen, Otchetpo revizii Turkestanskogo kraia, proizvedennoipo VYSOCHAISHEMU poveleniuu... (St. Petersburg: Senatskaia tipografiia, 1910), 12: Uezdnoe upravlenie, 156.

${ }_{87}$ Nikolai Karyshev, Zemskiia khodataistva 1865-1884 gg. (Moscow: A. A. Lang, 1900), 7; Burbank and von Hagen, "Coming into the Territory," 22.

${ }^{s 8}$ A. V. Remnev, "General-gubernatorskaia vlast' v XIX stoletii: K probleme organizatsii regional'nogo upravleniia Rossiiskoi imperii," in Imperskii stroi Rossii, 56.

s Kermit E. McKenzie, "The Zemstvo and Administration," in The Zemstvo in Russia: An Experiment in Local Self-Government, ed. Terence Emmons and Wayne S. Vucinich (Cambridge: Cambridge University Press, 1982), $34-35$.

${ }^{9}$ Theodore Weeks, Nation and State in Late Imperial Russia: Nationalism and Russification on the Western Frontier, 1863_1914 (DeKalb: Northern Illinois University Press, 1996), 133_51; Kimitaka Matsuzato, "The Issue of Zemstvos in Right-Bank Ukraine, 1864 -1905: Russian Anti-Polonism under the Challenges of Modernization," Jahrbucherfur Geschichte Osteuropas 51, 2 (2003): 218-35.

' L. E. Lapteva, Zemskie uchrezhdeniia v Rossii (Moscow: Institut gosudarstva i prava Rossiiskoi akademii nauk, 1993), 122.

${ }_{92}$ Zh. A. Kalmykov, Ustanovlenie russkoi administratsii v Kabarde $i$ Balkarii (Nal'chik:, El'brus, 1995), 20-29; Bobrovnikov, Musul'mane severnogo Kavkaza, 147—66; Michael Kemper, "'Adat against Shari'a: Russian Approaches towards Daghestani 'Customary Law' in the 19th Century," Ab Imperio, no. 3 (2005): 147—74. 
set about trying to eliminate military rule, beginning with judicial reforms. The Duma also debated the possibility of introducing zemstvos to the civilian gubernii of the region, but neither had been achieved before World War I broke out. ${ }^{93}$ The West Siberian governor-generalship was abolished in 1882, and Tomsk and Tobol'sk provinces were placed under the jurisdiction of the Ministry of the Interior, although the powers exercised by their governors remained more or less unchanged. ${ }^{94}$ Although in 1907 the Duma debated a project for the introduction of the zemstvo to Tobol'sk province, it was not passed into law, and zemstvos were extended to Siberia only by the Provisional Government in 1917.95 The East Siberian governor-generalship was subdivided into oblasts after 1884 but remained under military authority, something reinforced by the establishment of a Far Eastern viceroyalty as Russia moved into Manchuria and Port Arthur. ${ }^{96}$ The situation in the steppe was particularly complicated, with considerable fragmentation of authority: after 1881, with the abolition of the Orenburg and West Siberian governorgeneralships, the Stepnoi krai was created, comprising the Ural'sk, Turgai, Akmolinsk, Semipalatinsk, and (until 1898-99) Semirech'e oblasts, with military governors under the jurisdiction of the Ministry of the Interior. The latter three provinces constituted the governor-generalship of the Stepnoi krai, but all five were regulated under the revised Steppe Statute (Stepnoe Polozhenie) of 1891, which opened the way to increased Russian colonization by establishing the state's right to expropriate "surplus" nomadic land. ${ }^{97}$ In 1898, civilian courts and an independent judiciary were extended to the steppe, although their jurisdiction was limited almost exclusively to Russian settlers and Kazakhs retained their 'adat courts. ${ }^{98}$ There was also

L. S. Gatagova and D. I. Ismail-zade, "Kavkaz," in Natsional'nye okrainy, ed. Agadzhanov, 286-90, 309-15.

${ }^{9}$ A. V. Remnev, Upravlenie Sibiriu i Dal'nim Vostokom v XIX-nachale XX vv. (Omsk: Izdatel'stvo Omskogo gosudarstvennogo universiteta, 1991), 66-67.

${ }_{95}$ M. V. Ugriumova, "Zemskii vopros i zemskoe samoupravlenie v Tobol'skoi gubernii (vtoraia polovina XIX v.-1919 g." (abstract for Candidate of Historical Sciences diss., Tiumenskii gosudarstvennyi universitet, 2002), 27-28.

${ }^{6}$ A. A. Toropov, "Administrativno-territorial'noe delenie Sibiri i Dal'nego Vostoka," in Dal'nii Vostok Rossii: Iz istorii sistemy upravleniia. Dokumenty $i$ materialy (Vladivostok: Rossiiskii gosudarstvennyi istoricheskii arkhiv Dal'nego vostoka, 1999), 18-20.

${ }_{97}$ "Polozhenie ob upravlenii oblastei Akmolinskoi, Semipalatinskoi, Semirechenskoi, Ural'skoi i Turgaiskoi i ob izmenenii nekotorykh statei Polozhenii ob upravlenii Turkestanskogo kraia," Polnoe sobranie zakonov Rossiiskoi imperii: Sobranie tret'e, 33 vols. (St. Petersburg: Gosudarstvennaia tipografiia, 1895-1916) (hereafter PSZ3), no. 7574, 25 March 1891, 133^7.

9 Virginia Martin, Law and Custom in the Steppe: The Kazakhs of the Middle Horde and Russian Colonialism in the Nineteenth Century (Richmond, UK: Curzon, 2001), 56-57; N. E. Bekmakhanova, "Kazakhstan i Sredniaia Aziia," in Natsional'nye okrainy, 335-43. 
some official debate about the possible extension of zemstvos to the region, although with measures to ensure that Kazakhs could not form a majority on the zemstvo boards; this remained unrealized in 1917.90 Turkestan remained under military rule until the fall of tsarism, and the proposed introduction of zemstvos to the region by the Provisional Government never went into effect. Altogether, the leading tsarist historian of the zemstvo concluded, 43 provinces with a population of 110 million had zemstvos in 1917, while 51 provinces with a population of 61 million still lacked them..$^{100}$

This division between military and civilian government and between zemstvo and non-zemstvo provinces clearly did not imply the same degree of disparity of rights between metropole and colony which existed in Britain after the Reform Act of 1867 and in France after the establishment of the Third Republic. There was, nevertheless, a disparity, one that has often been overlooked by historians. In an otherwise convincing paper on the remarkable economic diversity that existed even within European Russia, David Saunders does not mention this important distinction in political rights between the 50-odd "core provinces" of the empire that he identifies and the borderlands under military rule. ${ }^{101}$ Jane Burbank describes how the imperial state assigned varying sets of rights to particular peoples, but the passage of local elites into the higher state bureaucracy which she mentions as characteristic of Russian statecraft was impossible in areas under military rule, as voenno-narodnoe upravlenie was predicated on a clear distinction between the higher (European) administration and lower-level native officials. In most cases, the "distinctive treatment of inorodtsy through separate legal codes and regulations" was thus not, as she argues, "entirely in accord with the way ethnic Russians were governed." ${ }_{102}$ Similarly, Robert Crews's attempt to provide a general survey of the Muslim relationship with the Russian state in the 19th century is undermined by his failure to appreciate the very different administrative and legal structures that existed in the Volga-Ural region and in Central Asia: the Muslims of Kazan province were full subjects of the Russian state, liable for conscription but also with access to jury trial, the zemstvo, and the Orenburg Spiritual Assembly. ${ }^{103}$ Even the neighbouring Bashkirs suffered certain legal

99 My thanks to Professor Tomohiko Uyama for alerting me to these points.

10. V. Veselovskii, Zemstvo i zemskaia reforma (Petrograd: O. N. Popova, 1917), 16.

${ }_{101}$ David Saunders, "Regional Diversity in the Later Russian Empire," Transactions of the Royal Historical Society, Sixth Series, 10 (2000): 143-63.

102 Jane Burbank, "The Rights of Difference: Law and Citizenship in the Russian Empire," in Imperial Formations, ed. Ann Laura Stoler, Carole McGranahan, and Peter Perdue (Santa Fe, N M : School for Advanced Research, 2007), 81, 93-94.

103 Crews, For Prophet and Tsar, chap. 5. 
disabilities by comparison, although they had a landowning nobility which, until the late 19th century at least, retained a number of important rights and privileges. ${ }^{104}$ None of this applied to the Kazakhs or to the inhabitants of Tashkent. A good example of the practical difference is offered by Norihiro Naganawa, who describes how, in the late 19th and early 20th centuries, there was an extensive debate among the Muslims of the Volga-Ural region as to whether the existing network of traditional and "new-method" maktabs should come under zemstvo control and form part of the national movement toward universal primary education. As he points out, however, no such debate was possible in Turkestan, since there were no zemstvos and the entire system of Muslim primary and secondary education remained almost entirely beyond state control. ${ }^{105}$ Such differences suggest that we should be very careful in putting forward the idea of a common "Muslim" experience of Russian imperial rule. Any attempt to create a broad overview of the empire's administrative policies, practices, and debates must incorporate the experience of the regions under military rule, in particular Central Asia.

The example of Turkestan, the largest and most populous region to remain continuously under military government until 1917, helps illuminate the official reasoning behind this division, together with some of its practical effects. Isolated geographically from European Russia by an expanse of steppe that took two months to cross by caravan, Turkestan was isolated still more decisively in the minds of tsarist officials by its dense, ancient, and settled Islamic culture. The difference was expressed in a vocabulary that persistently described the local population as turemtsy (natives) or even aborigines, emphasizing the degree to which the Russians were incomers to the region. ${ }^{106}$ It was also clearly laid out in urban planning, which followed the pattern of the cantonments of British India or the Villes nouvelles of French North Africa. By providing separate "Russian quarters" alongside older Central Asian towns, these "separate species" could live separately, as the famous travel writer Evgenii Markov put it. ${ }^{107}$ Vladimir Bobrovnikov has noted that the

104 Steinwedel, "Invisible Threads of Empire," 91-95.

${ }_{105}$ Norihiro Naganawa, "Maktab or School? Introduction of Universal Primary Education among the Volga_Ural Muslims," in Empire, Islam, and Politics, 65—97.

10 Khalid, "Culture and Power," 419-20. See, for instance, N. A. Maev, Turkestanskaia vystavka 1890g.: Putevoditel' po vystavke i ee otdelam (Tashkent: n.p., 1890), 4.

10 E. Markov, Rossiia v SredneiAqui: Ocherkiputeshestviiapo Zakavkaz'iu, Turkmenii, Bukhare, Samarkandskoi, Tashkentskoi i Ferganskoi oblastiam, Kaspiiskomu moriu i Volge (St. Petersburg: 
system of voenno-narodnoe upravlenie developed for Turkestan was modeled in part on the one developed over the previous 20 years in the Caucasus, where many of the first generation of Turkestani officers had served. ${ }^{108}$ Memories of the Caucasus War also helped ensure that the chief marker of the population's difference would be religion, and there was a widespread assumption among most of Turkestan's officers that most Muslims were "fanatics." Accordingly, the first governor-general, Konstantin Petrovich von Kaufman, adopted an official policy of "ignoring" Islam, which led to the exclusion of the region from the jurisdiction of the Orenburg Muslim Spiritual Assembly. ${ }^{109}$ In practice, the authorities were forced to preserve and work with many religious institutions such as the qazis courts and religious endowments, but this was an unwilling product both of a lack of resources and a deep-seated fear that excessive interference in religious institutions and practices could provoke revolt, not a continuation of earlier tsarist policy, which saw the co-optation of Islam by the state as a positive good.

Even when elements of Turkestan's administration were ostensibly modeled on practice in European Russia, the consequences were very different. For the peasants of European Russia, the sel'skoe obshchestvo became the basic tax-paying and administrative unit under the 1861 reforms and may have constituted a formalization of the existing peasant commune. In Turkestan, by contrast, it was an entirely artificial construct, lumping together groups of villages that had never before formed administrative units and creating new local oligarchies.10 Grąhdanstvennost' was frequently invoked by the officers responsible for Russian administrative policy in the settled regions of Central Asia, and inculcating this elusive quality remained a permanent but everreceding goal for the Russian administration. ${ }^{111}$ By the 1880 s, there were calls for greater administrative sblizhenie through the introduction of elements of civilian rule. The clearest statement both of the role the Russians felt should be played by voenno-narodnoe upravlenie, and their planned timetable for

M. M. Stasiulevich, 1901), 421—22; Sahadeo, Russian Colonial Society, 85—87.

ios Bobrovnikov, Musul'mane severnogo Kavkaza, 169-70.

109 Gen.-Ad"t. K. P. fon-Kaufman, Proekt V sepoddanneishego otcheta Gen.-Ad"iutanta fonKaufmanapo Grazhdanskomu upravleniiu (St. Petersburg: Voennaia tipografiia, 1885), 10.

11. Jane Burbank, "Thinking like an Empire: Estate, Law, and Rights in the Early Twentieth Century," in Russian Empire, 201; Sergei Abashin, "Obshchina v Turkestane v otsenkakh i sporakh russkikh administratorov nachala 80-kh gg. XIX v.," in Sbornik Russkogo istoricheskogo obshchestva 5 (153) (Moscow: Russkaia panorama, 2002), 71—88; Beatrice Penati, "Swamps, Sorghum, and Saxauls: Marginal Lands and the Fate of Russian Turkestan (c. 1880-1915)," Central Asian Survey 29, 1 (2010): 61-78.

11 For an influential view, see L. F. Kostenko, Sredniaia Aquïa i vodvorenie v nei Russkoi grazhdanstvennosti (St. Petersburg: V. Bezobrazov, 1871). 
replacing it, can be found in the report of Senator Fedor Karlovich Giers, who was commissioned by the second governor-general of Turkestan, General Mikhail Grigor'evich Cherniaev, to produce recommendations to reform Turkestan's governing statute (and, not coincidentally, to blacken the name of his hated predecessor, von Kaufman).

The business of military power is to conquer and pacify a conquered region; the further pacification, development, and organization belong entirely to the civil power. Military-popular government [voennonarodnoe upravlenie] is essential only for the first period after the conquest of a country; thereafter, as the region becomes calmer, it slows the civil [grazhdanskoe] development of the people. The Turkestan krai, as is visible from the above [evidence], is so far pacified that the time has come for its further rapprochement [sblizhenie] to Russia by means of such unifying of its administration with the general arrangements of the empire as are possible. ${ }^{112}$

The new Turkestan statute which eventually resulted in 1886 introduced elements of the new civil code to Turkestan, but these continued to be administered by military courts. It did nothing to dilute the military monopoly on administration in the region, let alone bring any closer the introduction of civic institutions such as the zemstvos. ${ }^{113}$ In the end, such high-minded sentiments always foundered on pessimism over the cultural distance that lay between Russians and Muslims. Daniel Brower's work shows clearly how proposals to extend civilian rule and introduce all-imperial norms of governance and grazhdanstvennost' were invariably stymied by officers who insisted on the maintenance of the priorities of military security - whether against Muslim "backwardness" and "fanaticism" or new pan-Turkic and pan-Islamic threats. ${ }^{114}$ This debate became particularly pronounced in the aftermath of the Andijan uprising of 1898, when some argued that the revised 1886 statute of governance had weakened and demilitarized Turkestan's administration too much. ${ }^{15}$ The uprising also helped revive the belief that Turkestan's Muslims were dangerous "fanatics" and set the cause of civilian

\footnotetext{
${ }_{12}$ F. K. Girs, Otchet, revizuiushchego, po Vysochaishemupoveleniiu, Turkestanskogo kraia, Tainogo sovetnika Girsa (St. Petersburg: n.p., 1884), 462.

113 "Polozhenie ob upravlenii Turkestanskogo Kraia," PSZ3, no. 3814, 12 June 1886, $318-46$.

11. Daniel R. Brower, Turkestan and the Fate of the Russian Empire (London: Routledge, 2003), 9-25, 105-6.

115 V. P. Sal'kov, "Andizhanskoe Vosstanie" v 1898 g. (Kazan: Tipografiia Imperatorskogo universiteta, 1901), 92-93.
} 
government back substantially. ${ }^{116}$ In the very last years of Russian rule, even the most liberal officials felt that any real sblizhenie between Russian and "native" was as far away as ever."17

The legal and administrative exclusion of the natives of Central Asia from the new civic structures of the Russian state became ever clearer as that state sought gradually to modernize itself and introduce wider forms of political participation. Muslims in Central Asia were not included in the state's putatively universal registers of births, deaths, and marriages, the metrical books, as the state-sponsored religious hierarchy needed to administer them did not exist in Central Asia. ${ }^{118}$ The introduction of an individually assessed income tax, as Yanni Kotsonis has shown, was intended to play a crucial role in ending collective responsibility and turning Russian subjects into individual citizens. Although he does not mention Central Asia (where the land tax was the main form of assessment), the experience of the Far East, where officials decided that Korean and Chinese laborers constituted "halfpersons" for tax purposes, is suggestive. ${ }^{119}$ More important, perhaps, the entire Muslim population of Central Asia (including not only the recently conquered sedentary peoples of Turkestan but also the Kazakhs, many of whom had been Russian subjects for over 100 years) was exempted from the new conscription law of 1874. Though exemption could be regarded as a privilege, it also clearly signaled their exclusion from the putative political community of the Russian Empire. Miliutin and his fellow-reformers may have believed in the power of military assimilation in creating a Russian nation, but only up to a point. ${ }^{120}$ This is why, by the early 20th century, many Kazakh intellectuals supported the extension of conscription to their people in the hope that it would also lead to the extension of the zemstvo to their provinces. Governor-General von Kaufman and the military governors of the provinces of Turkestan, however, argued that subjecting the Muslim

\footnotetext{
116 For particularly virulent Islamophobia, see E. T. Smirnov, "Dervishizm v Turkestane," and "Dzhikhad i Gazavat," in Sbornik materialovpo Musul'manstvu, 1, ed. V. I. Iarovoi-Rabskii (St. Petersburg: M. Rosenoer, 1899), 49-71, 101-28; and M. A. Miropiev, Opolozhenii russkikh inorodtsev (St. Petersburg: Sinodal'naia tipografiia, 1901).

11 N. S. Lykoshin, Rezultaty sblizheniia russkikh s tuzemtsami (Tashkent [?]: n.p., 1903); Lykoshin, Pol zhizni v Turkestane: Ocherki byta tuzemnogo naseleniia (Petrograd: V. A. Berezovskii, 1916), 5-16; V. P. Nalivkin, Tuzemtsy, ran'she i teper' (Tashkent: A. Kirsner, 1913), 69.

118 Paul Werth, "In the State's Embrace? Civil Acts in an Imperial Order," Kritika 7, 3 (2006): 441-42.

11. Kotsonis, " 'Face-to-Face,'" 241-43; Kotsonis, "'No Place to Go,'" 556-58.

120 Joshua Sanborn, Drafting the Russian Nation: Military Conscription, Total War, and Mass Politics, 1905-1925 (DeKalb: Northern Illinois University Press, 2003), 9-14, 21.
} 
population of the region to military service would simply supply training and leadership for future insurrections against Russian rule; even in the steppe, officials felt that the Kazakhs were too distant from grazhdanstvennost $\}^{\prime}$ In the late 19th and early 20th centuries, this reluctance to conscript inorodtsy was reinforced by the supposedly scientific work of military anthropologists, which alleged their lack of martial qualities when compared to Russians..$^{122}$ The eventual promulgation of a conscription $u k a$ z in Central Asia in July 1916 (even then only for Muslims to serve in labor battalions, not on equal terms) did indeed provoke widespread armed rebellion, although this was as much a pent-up response to wartime tax increases and the increasing encroachment of Russian settlers as it was to military service itself.

If conscription, registration, and taxation can all be seen as oppressive or coercive functions of the modern state from which Russia's colonial subjects might have been happy to be free, the restriction of the state's gaze in these regions also led to a restriction ofrights ofparticipation in the empire's fledgling democratic institutions. Municipal government was extended to the largest cities in Muslim regions only in the late 1870s, and in Baku and Tashkent the franchise was carefully manipulated to ensure Russian preponderance..$^{123}$ In the latter city, the Muslim population paid the bulk of the taxes, but these were largely spent on tramways and lighting in the European Nouvelle Ville, which was distinct from the native city. ${ }^{124}$ With the more significant extensions of political rights in the Russian Empire after the 1905 October Manifesto, inequalities were thrown into even sharper relief. The Muslims of the Russian Empire were granted 36 seats in the new State Duma, but in Turkestan Russians and "natives" were divided into separate constituencies, and even though the latter made up over 90 percent of the population, they elected just six deputies, while the Russian population elected seven. The franchise was strictly limited to those with property and knowledge of Russian; and elections were indirect, through four stages rather than two as in European Russia. ${ }^{25}$ Some of the liberals in Tashkent who had campaigned vociferously for universal secret, equal, and direct suffrage were troubled but

\footnotetext{
121 Uyama, "A Particularist Empire," 25, 40-44.

122 Mogil'ner, Homo imperii, 337-446.

123 Mostashari, On the Religious Frontier, 69-70.

12. Sahadeo, Russian Colonial Society, 83, 94-95; David Saunders thus misses the point somewhat when he says that without the Russian conquest in 1865 , there would have been no tramways in Tashkent ("Regional Diversity," 156): it was the native population who paid for them and the European settlers who principally benefited.

125 Adeeb Khalid, The Politics of Muslim Cultural Reform: Jadidism in Central Asia (Berkeley: University of California Press, 1997), 233-35.
} 
eventually reconciled the results with their consciences by reasoning that the Muslim population of the region was extremely reactionary and would probably vote for conservatives if given equal rights. ${ }^{126}$ In any case, the First Duma was dissolved before elections could be held in Turkestan. After the dissolution of the Second Duma, these seats were abolished; and Turkestan and the Stepnoi krai were denied representation altogether. Only ten Muslim deputies were elected to the Third Duma, and seven to the Fourth, five of whom were Tatars. ${ }^{127}$ Turkestanis were not indifferent to political exclusion: in 1908, some of the inhabitants of Samarkand protested against their lack of representation in the Third Duma in a petition submitted to Count Konstantin Konstantinovich von der Pahlen's reforming commission, in which they stated that the few Muslim deputies from other regions were unable to represent them adequately, their way of life being quite different from that of other Muslims of the empire. ${ }^{128}$ Pahlen did propose the extension of civilian administration to Turkestan, and even of zemstvos with a preponderant official element. ${ }^{129}$ He too, however, viewed Turkestan as a colonial region with particular, colonial problems, writing, "her governmental needs are very different from those which come to be applied in the heart of the empire," and suggesting that the region should be given greater administrative autonomy as a "colony within the empire" along the lines of British India. ${ }^{130}$ In any case, these proposals were blocked by the determination of the local military bureaucracy to maintain its monopoly on administration, and of the Central Administration for Agriculture and Land Management (Glavnoe upravlenie zemledeliia i zemleustroistva) to bring about a more "rational" exploitation of Turkestan's resources through an accelerated program of Russian peasant

126 Sahadeo, Russian Colonial Society, 139-41.

127 R. A. Tsiuniuk, "Razvitie politicheskoi zhizni musul'manskikh narodov Rossiiskoi imperii i deiatel'nosti musul'manskoi fraktsii v Gosudarstvennoi dume Rossii 1906-1917 gg.," in Imperskii stroi Rossii, 201-2, 211.

128 "Petitsiia tuzemtsev g. Samarkanda i uezda," 10 October 1908, Rossiiskii gosudarstvennyi istoricheskii arkhiv (RGIA) f. 1396, "Reviziia Senatora Palena K. K. Turkestanskogo Kraia v 1908-1910 g.," op. 1, d. 264, 11. 230-37ob. (http://zerrspiegel.orientphil.uni-halle.de/t896. html, accessed 5 October 2010).

${ }_{129}$ This provoked considerable disquiet, as the official press warned that the native population was still too backward and, above all, too "unknown" for such innovations to be risked. See Golovin, "O vvedenii zemstva v Turkestane," Turkestanskie vedomosti, nos. 15-18 (1910), in Turkestanskii sbornik 535: 47-57.

13 Senator Graf K. K. Palen, V sepoddanneishaia zapiska, soderzhashchie glavneishie vyvody otcheta (St. Petersburg: Senatskaia tipografiia, 1910), 12. 
resettlement (pereselenie), part of what Willard Sunderland has referred to as the "colonialization" of Asiatic Russia in the later 19th century. ${ }^{13}$

In no other area, perhaps, was the inequality of rights between Russians and "natives" within the empire as clear as in pereselenie, which was clearly predicated on the idea that Russians (or, more broadly, Europeans) had a preeminent right to the empire's land, one that trumped the rights of the native population in Turkestan and the Stepnoi krai. Pereselenie primarily affected the Kazakhs and Kyrgyz, who saw their pasturelands eroded by colonization and who, as they turned to settled agriculture, competed increasingly fiercely with arriving colonists for arable land and water. ${ }^{132}$ Peter Holquist has recently referred to a "technocratic ideology" developing within the institutional culture of the Resettlement Administration, where the liberal or even revolutionary ideals of its officials helped generate a ruthless attitude toward the "backwardness" of nomadic pastoralists. ${ }^{133}$ Aleksandr Arkad'evich Kaufman, the doyen of Russian agronomists and resettlement experts, was also a leading light of the Constitutional Democratic (Kadet) Party and saw no contradiction between its platform of securing legal and political rights for the population of the empire at large and the expropriation of the Kazakhs. He dismissed Kazakh representatives in the Kadet Party as self-interested "bais and sultans" and simply refused to recognize their claim to the land. ${ }^{134}$ Both pereselenie and a democratic constitution could be harnessed to a particular idea of "progress"; and in any case, he and most other officials of the Resettlement Administration shared the assumption that the good of the empire was synonymous with the good of the Russian "nation." As Georgii Gins, perhaps the most prominent of the young "technocrats" identified by Holquist, put it in a response to a new draft water law for Turkestan in 1911:

The slow growth in the numbers of the Russian population of the region has long given the advantage to the conservative tendency over that of

13. Willard Sunderland, "The Ministry of Asiatic Russia: The Colonial Office That Never Was but Might Have Been," Slavic Review 69, 1 (2010): 120-50. See also Brower, Turkestan, $140^{\wedge} 5$.

132 Martin, Law and Custom, 72-73; Stephen Sabol, Russian Colonization and the Genesis of Kazakh National Consciousness (Basingstoke, UK: Palgrave Macmillan, 2003), 42-44.

${ }_{13.3}$ Peter Holquist, " 'In Accord with State Interests and the People's Wishes': The Technocratic Ideology of Imperial Russia's Resettlement Administration," Slavic Review 69, 1 (2010): 151-79.

13. A dispute between Kaufman and the Kazakh lawyer Zhikhansha Seidalin on this question was played out in the pages of the Kadet newspaper Rech': A. Kaufman, "Kirgizy i Konstitutsionno-demokraticheskaia partiia," Rech', no. 11 (5 March 1906); Zh. Seidalin, "Kirgizskii vopros?" Rech', no. 27 (21 March 1906); and A. Kaufman, "K kirgizskomu voprosu!" Rech, no. 32 (27 March 1906). 
cultural constructiveness and ofAsiaticness [here Gins used the pejorative term Aziiatshchina] over European influences. This is why, while we relate to the native population with complete goodwill, we cannot fail to repeat that limits must be placed upon the further expansion of the area of native agriculture, and that everything remaining beyond these limits must be transferred to the Russian population. ${ }^{135}$

The new water law, eventually passed in 1916, was designed to break the control that the local population still retained over the distribution of water and to facilitate the activities of private enterprise in irrigating expropriated "state land" to render it suitable for Russian settlement. ${ }^{136}$ In a well-known report on the future of the "colony," as he called it, based on a visit to Turkestan in 1912, Gins's superior, Aleksandr Vasil'evich Krivoshein, envisaged far more extensive programs for peasant resettlement and the agrarian exploitation of Central Asia than had ever before been contemplated. He also contradicted the Pahlen Commission in saying that military rule had hitherto had no adverse effects on the economic development of the region and that it should be preserved for the time being:

The question of the substitution of military with general civil rule [obshchegrazhdanskoe] in Turkestan or the proposal of Count Pahlen for the introduction of zemstvos to the region appears distant and comparatively minor. Both the former and the latter reform are matters for the future. Both are useful, good, and beneficial, but only with a sufficient Russian population in the region. ${ }^{137}$

Turkestan's Russianness, and therefore its right to the institutions of the European provinces of the empire, would be determined by the number of Russian settlers with which the state could flood it: the "natives" could not be trusted. The brutal suppression of the 1916 revolt rendered this exclusion still clearer. The "solution" proposed by the last governor-general, Aleksei Nikolaevich Kuropatkin, to the inter-ethnic violence that had broken out between natives and settlers in Semirech'e would have been little short

135 G. Gins, "Usloviia orosheniia i ekspluatatsii chastnymi predprinimateliami svobodnykh zemel' Turkestana i Zakavkaz'ia," Voprosy kolonizatsii, no. 8 (1911): 251.

${ }_{136}$ And not, as has recently been suggested, to restrict private control over water in favor of a newly minted notion of "public property." See Ekaterina Pravilova, "Les respublicae russes: Discours sur la propriete publique a la fin de l'empire," Annales des hautes etudes en sciences sociales, no. 3 (2009): 592—93; See also "Zakonoproekt Glavnogo upravleniia zemleustroistva i zemledeliia po otdelu zemel'nykh uluchshenii, o proizvodstve za schet chastnykh sredstv orositel'nykh rabot v Turkestane," Voprosy kolonizatsii, no. 14 (1914): 222-26.

137 A. V. Krivoshein, Zapiska Glavnoupravliaiushchego zemleustroistvom i zemledeliem opoezdke v Turkestanskii krai v 1912godu (St. Petersburg: Gosudarstvennaia tipografiia, 1912), 78. 
of apartheid: the creation of an all-Russian district in the fertile region around Lake Issyk-Kul and the deportation of its Kyrgyz population to a mountainous Bantustan in the region of Naryn. ${ }^{138}$ The February Revolution brought a halt to these plans, but it also provided a further test of Russian settler attitudes; the Provisional Government in Petrograd granted full citizenship to the native population, introducing zemstvos and municipal government and allowing the region equal representation in the proposed Constituent Assembly. ${ }^{139}$ Even liberal and revolutionary Russians objected, asking for special exemptions, such as separate dumas for the Russian and native quarters of cities and separate electorates to the assembly to ensure preponderant Russian representation. The justification was ostensibly neither racial nor religious but developmental: the turemtsy were as yet unready for self-government. This argument was also reflected in the first decree of the Tashkent soviet after the October Revolution, which barred Muslims from admission among its delegates on the grounds that they had not yet developed a proletariat. ${ }^{40}$ The attempt by the Turkestan Bolsheviks to establish what would have been a settler-controlled state eventually had to be suppressed by forces sent from Moscow. ${ }^{1+1+}$

The widespread assumption among historians that the assimilation of the peoples and territories of the empire into a single administrative and cultural whole was the ultimate aim of Russian imperialism thus needs to be substantially qualified. Peter Waldron suggests that Russia's rulers regarded all borderland regions "as areas to be assimilated into the metropolitan state, rather than colonies to be subdued." ${ }_{122}$ For Anatolyi Remnev, "the Russian imperial project envisaged the gradual absorption of the periphery by the Imperial core," largely by means of peasant colonization, which he characterizes as "a cardinal difference between the Russian Empire and the

13 P. Galuzo, ed., "Vosstanie 1916 g. v Srednei Azii," Krasnyi arkhiv 34 (1929): 60.

13. Veselovskii, Zemstvo i zemskaia reforma, 29, 33, 44; he noted that special arrangements would be needed in nomadic regions, in particular because of the poor relations which existed between the local population and the settlers.

140 Adeeb Khalid, "Tashkent 1917: Muslim Politics in Revolutionary Turkestan," Slavic Review 55, 2 (1996): 279-80; Marko Buttino, Revoliutsiia naoborot: Sredniaia Aziiia mez̧du padeniem tsarskoi imperii i obrazovaniem SSSR (Moscow: Zven'ia, 2007), 204-9.

${ }^{4}$ Dov Yaroshevski, "Russian Regionalism in Turkestan," Slavonic andEast European Review 65, 1 (1987): 77-100, gives an account of this episode, in which Muslims and their exclusion from the "regional" particularist politics of the new Turkestan Republic are rather invisible.

142 Waldron, Governing Tsarist Russia, 138. 
Western colonial empires." ${ }_{43}$ The appropriation of territory and erasure of cultures and peoples through settler colonialism is, of course, hardly a peculiarly Russian characteristic. Beyond this, however, similar projects of assimilation to the metropole through colonization existed in both the British and French empires, most obviously in the cases of Ireland and Algeria. Both empires also saw more ambitious attempts to create wider unions: in the British case by drawing the white settler dominions into union with the "mother country" under a single imperial Parliament, an idea popularized by Sir John Seeley in his 1883 classic, The Expansion of England, but which remained current well into the 1930s. ${ }^{14+}$ In the French case, the legacy of the postwar attempt to assimilate colonies to the metropole can still be seen in the anomalous presence of Reunion, Martinique, Guadeloupe, and French Guyana on euro currency notes: they remain metropolitan French territory to this day. The difference was therefore not qualitative; it was simply that in the British and French case ambition far outstripped political and demographic realities and was unable to overcome cultural and geographical distance. This was true for some parts of the Russian Empire as well. Remnev's model makes sense for Siberia, where the complete cultural Russification of the territory through colonization was more or less complete by the beginning of the 20th century. As Willard Sunderland has shown, a similar process took place on the steppes of what would become southern Ukraine, although here the European culture that overlaid earlier nomadic memories was rather more cosmopolitan. ${ }^{45}$ On the Asian steppe, however, it proved a much more distant goal; and in Turkestan the aim of assimilation was so repeatedly postponed as to become effectively a dead letter. Instead, as we have seen, the final years of tsarism saw a much more aggressive policy of Russian settlement and economic exploitation proposed for the region, which was explicitly described as a "colony." ${ }_{46}$ Mark Bassin has suggested that unlike the vision of British imperial unity sketched out by Seeley in The Expansion of England, which excluded India, the tsarist empire had a "commitment to equal enfranchisement" which extended across all the empire's borderlands,

${ }_{143}$ A. V. Remnev, "Siberia and the Russian Far East in the Imperial Geography of Power," in Russian Empire, 440-41.

14 On this point, see Duncan Bell, The Idea of Greater Britain: Empire and the Future of World Order, 1860-1900 (Princeton, NJ: Princeton University Press, 2007).

14 Willard Sunderland, Taming the Wild Field: Colonization and Empire on the Russian Steppe (Ithaca, NY: Cornell University Press, 2004).

${ }^{4} 4$ Krivoshein, Zapiska, 70; David Mackenzie, "Turkestan's Significance to Russia," Russian Review 33, 2 (1974): 182; S. N. Abashin, D. Iu. Arapov, and N. E. Bekmakhanova, eds., Tsentral'naia Aziia v sostave Rossiiskoi imperii (Moscow: Novoe literaturnoe obozrenie, 2008), 328-29; Sunderland, "The Ministry of Asiatic Russia." 
including Turkestan, but this is surely exaggerated. ${ }^{n t}$ Just as Seeley excluded India, so Central Asia remained a land apart, both in the Russian imperial imagination and, more important, in legal and administrative terms; it was regarded as inassimilable until the fall of tsarism.

There are also limitations to Burbank's model of an "Imperial Rights Regime." She is certainly right to warn us against the assumption that in the 19th century, regimes that claimed to espouse equal rights were necessarily any more just and humane than Russia, whose rather ramshackle system included separate courts for peasants and the exemption of "aliens" from the burden of military service. The example of British India, where in theory the rule of law was applied uniformly, is a clear enough reminder of that. ${ }^{148}$ However, in the Russian Empire in the second half of the 19th century, a definite pattern emerged, as certain rights were gradually extended at the center but withheld from the majority of the empire's "Asiatic" subjects because of their perceived underdevelopment. Russia's liberals dreamt of universal and equal imperial citizenship, but many of them became uneasy when it was suggested that this could be extended to more "backward" peoples or ignored the degree to which this task was complicated by the diversity of the empire's population. ${ }^{149}$ The imperial Russian state at times withheld and distributed political rights according to religious, cultural, or even ethnic criteria. ${ }^{150}$ It did not do so as consistently as the West European empires, but in some respects it, too, made the same distinctions between metropole and colony, between a European (if not Russian) ruling class, and the Asiatic masses, and, as Alexei Miller and Leonid Gorizontov have argued, between a truly Russian, national territory and areas that would always be inassimilable. ${ }^{151}$ Just how this tendency would have developed had it not been for the October Revolution is unclear: the

147 Bassin, "Geographies of Imperial Identity," 57-58.

i * Burbank, "An Imperial Rights Regime," 398-99. In India, admittedly, a version of what we might call a variable rights regime also existed, in the form of codes of Hindu and Muslim personal law that were incorporated into the Indian Penal Code, but in principle at least British Indian subjects had more personal rights and greater equality and protection before the law than Russian subjects did. This did not prevent the government of India from being an unrepresentative and despotic regime that privileged Englishmen.

1. 9 See Eric Lohr's discussion of the ideas of the liberal jurist V. M. Gessen in "The Ideal Citizen and Real Subject in Late Imperial Russia," Kritika 7, 2 (2006): 189—90.

150 Apart from the Jewish case discussed in Avrutin, "Racial Categories and the Politics of (Jewish) Difference," 13-40, Charles Steinwedel argues convincingly that the tsarist state did constitute and then use categories of ethnicity in Bashkiria from the 1890s onward ("To Make a Difference: The Category of Ethnicity in Late Imperial Russian Politics, 1861_1917," in Russian Modernity, 68-70, 73-75).

${ }_{151}$ Alexei Miller, The Romanov Empire and Nationalism (Budapest: Central European University Press, 2008), 161_79; Leonid Gorizontov, "The 'Great Circle' of Interior Russia: 
tension that emerged in 1917 between a liberal regime at the center and European settlers in Central Asia anxious to preserve or extend their privileges is more than a little reminiscent of the later divisions between metropolitan France and the pieds-noirs of Algeria, or the events that led to the Unilateral Declaration of Independence by settlers in Rhodesia.

The division between metropole and colony within the British and French empires and their failure and unwillingness to develop a genuine form of imperial citizenship are so well known as to be entirely uncontroversial. For the Russian Empire, despite the volume of high-quality scholarship that has recently been produced on Russian imperialism, the division remains much less well understood. I would suggest that this is, at least in part, because Russia's "imperial turn" coincided, more or less, with the wider "cultural turn" in the history of imperialism and colonialism. As Laura Engelstein has suggested, a relentless focus on supposedly stable cultural formations can blind historians to processes of change. ${ }^{152}$ In the case of the British Empire, the "cultural turn" in the history of imperialism from the late 1970s onward, despite its more incomprehensible excesses, was by and large a welcome corrective and supplement to what had gone before. Traditional historiography, exemplified in the old Cambridge History of the British Empire, was heavily political, with a relentless focus on structures of governance and, in particular, a deceptive portrayal of smooth constitutional progress toward self-government and independence in British colonies. ${ }^{153}$ That historiography did, however, at least banish any doubt as to the legal status of the different parts of the empire or the varying political rights of its citizens. The historiography of the Russian Empire was never blessed with such an embarrassment of riches. One consequence is that the first generation of English-language monographs on Russian imperialism that appeared from 1991 onward has left an admirable superstructure of cultural history - in particular, the history of national and religious identities and of Islamic reformism - without establishing solid foundations in the history of the military, bureaucracy, taxation, and other institutions of the Russian Empire. ${ }^{\text {ss }}$

Representations of the Imperial Center in the Nineteenth and Early Twentieth Centuries," in Russian Empire, 67-93.

152 Laura Engelstein, "Culture, Culture Everywhere: Interpretations of Modern Russia across the 1991 Divide," Kritika 2, 2 (2001): 363-64: however, the rest of this article is largely a celebration of the riches brought by the "cultural turn" in Russian history and does not seek to identify the areas that suffered relative neglect.

${ }^{5} 3^{3}$ J. Holland Rose et al., eds., The Cambridge History of the British Empire, 8 vols. (Cambridge: Cambridge University Press, 1929-59).

15 4 Dominic Lieven points out that many of these topics — particularly military history — have simply been very unfashionable over the last 20 years ("Introduction," in Cambridge History of Russia, 2:3). 
As Kimitaka Matsuzato has put it, thanks to Andreas Kappeler's pioneering work we have a much better understanding of the Russian Empire as a multi $\neg$ ethnic polity, but should we really be thinking of it in those terms at all, given how many of these "ethnicities" seem to have been at least partially constructed in the early Soviet period? Instead, he has urged that much greater attention be paid to the actual administrative units into which the empire was divided: provinces, oblasts, uezds, eparchates, and, more broadly, areas under civilian and under military rule. ${ }^{155}$

Naturally the legal, political, and administrative cannot be separated from the cultural when we try to understand divisions and inequalities: as we have seen, it was a developmental understanding of humanity closely akin to British or French attitudes which led the Russian state to restrict the rights it gave to its Asian subjects because they were "backward" and to Jews and the peoples of the western borderlands because they were "untrustworthy." For precisely this reason, however, such cultural justifications for inequality are a phenomenon easily comprehensible to all historians of 19th-century imperialism. The complexities and specificities of the legal and administrative regimes of the Russian Empire, in contrast, can only really be analyzed and explained by those who specialize in its history, or indeed in the history of particular regions within it. The process of writing this article and listening to the criticisms of other scholars revealed the enormous number of local variations which existed even among zemstvo provinces, or between different areas under voenno-narodnoe upravlenie. Just as it is easy for a historian of European Russia to overlook the colonial nature of Turkestan's administration, so (as I have discovered) a historian of Turkestan can easily fail to appreciate the differences that existed between the military regime there and that in the steppe governor-generalship, can mistakenly assume that Kazan and Ufa provinces were governed under the same legal regime, or lump the Volga-Ural region together with the western borderlands as part of a single, European "metropole." If the Russian Empire lacked the bewildering heterogeneity of the British, with its patchwork of self-governing dominions, crown colonies, and protectorates, it had more subtle variations of its own, which are often very difficult to grasp.

Finally, this complex picture of pluralism and inequality has implications for our understanding not just of the tsarist state but of the Soviet regime that followed it. After 1917, even the most "backward" peoples of the Russian Empire would become full Soviet citizens - however empty that title may have been, it was equally empty for all nationalities and all territories. Instead,

15 s Matsuzato, "General-gubernatorstva," 427-32, 456-58. 
party members of whatever nationality received certain privileges, while those designated as class enemies, such as the Cossacks or the Central Asian ulama, were excluded from the Soviet political community (though sometimes, of course, as with the Poles in the 1930s or the Chechens in the 1940s, this logic was applied to particular peoples). This commitment to a single citizenship existed precisely because the Soviet Union was far more ambitious and ruthless in its plans to modernize its subjects and remake them anew than the tsarist empire had ever been: in this, as in other respects, it more closely resembled the contemporary modernizing regimes in Turkey and Iran than it did its predecessor. ${ }^{18}$ In other areas, there were continuities, but there is a distinction between a tsarist state which distributed rights, obligations, and civic participation unequally among different peoples and territories and a Soviet Union whose vision of citizenship, and the citizens it was supposed to create, was universal.

Dept. of History

University of Liverpool

9 Abercromby Square

Liverpool L69 7WZ, United Kingdom

A.S.Morrison@liverpool.ac.uk

156 Adeeb Khalid, "Backwardness and the Quest for Civilization: Early Soviet Central Asia in Comparative Perspective," Slavic Review 65, 2 (2006): 231—51. 